\title{
Teacher Emotions in Primary and Secondary Education: Effects of Self-Efficacy and Collective-Efficacy, and Problem-Solving Appraisal as a Moderating Mechanism
}

\author{
Georgia Stephanou1, Anastasia Oikonomou ${ }^{2}$ \\ ${ }^{1}$ Faculty of Education, University of Western Macedonia, Florina, Greece \\ ${ }^{2}$ Hellenic Open University, Patra, Greece \\ Email: gstephanou@uowm.gr
}

How to cite this paper: Stephanou, G., \& Oikonomou, A. (2018). Teacher Emotions in Primary and Secondary Education: Effects of Self-Efficacy and Collective-Efficacy, and Problem-Solving Appraisal as a Moderating Mechanism. Psychology, 9, 820-875. https://doi.org/10.4236/psych.2018.94053

Received: March 10, 2018

Accepted: April 27, 2018

Published: April 30, 2018

Copyright (c) 2018 by authors and Scientific Research Publishing Inc. This work is licensed under the Creative Commons Attribution International License (CC BY 4.0).

http://creativecommons.org/licenses/by/4.0/

\section{(c) (i) Open Access}

\begin{abstract}
This study aimed to examine: 1) teachers' self-reported emotions experienced at school, problem-solving appraisal, self-efficacy and school collective-efficacy; 2) the effects of self-efficacy on the formulation of collective-efficacy and problem-solving appraisal, and on the impact of problem-solving appraisal on collective-efficacy; 3) the influential role of efficacy beliefs, problem-solving appraisal and their inter-effects in the emotions; and 4) the effect of teaching level (primary/secondary school) in the examined concepts. The sample consists of 256 primary and secondary school teachers, 92 men and 164 women, who came from various Greek state schools. Data were collected at the middle of a school year, and they were analyzed between and within groups across all constructs. The results revealed: 1) teachers experienced positive emotions from moderate to high intensity, and negative emotions from low to high intensity, particularly context-, task- and self-related; 2) a moderate to high sense of both efficacy beliefs and problem-solving appraisal (except for personal control that was low); 3) while problem-solving appraisal influenced collective-efficacy, its effect was to a significant extent mediated by self-efficacy; 4) self-efficacy, problem-solving appraisal and collective-efficacy had complimentary impact on the emotions, with self-efficacy being the most powerful formulator of most of them; and 5) the primary school teachers, compared to secondary school teachers, felt more intense positive emotions, had a stronger sense of school collective-efficacy and reported lower impulsive and personal control in problem-solving. The findings are discussed with re-
\end{abstract}


spect to their practical applications and future research.

\section{Keywords}

Emotions, Efficacy Beliefs, Problem-Solving Appraisal, Teacher, Teaching Level

\section{Introduction}

Teachers' emotions are essentially related to various situations relevant to their professional duties and affect a variety of important outcomes, such as their own well-being and health (e.g., Chang, 2009; Fried, Mansfield, \& Dobozy, 2015; Keller, Chang, Becker, Goetz, \& Frenzel, 2014), motivation, behavior and classroom effectiveness (e.g., Beach \& Pearson, 1998; Csikszentmihalyi, 1990; Fredrickson, 2001; Hargreaves, 2000; Isen, 1993; Sutton, 2005) and self-identity (Schutz \& DeCuir, 2002; Somech \& Drach-Zahavy, 2000), students' emotions, well-being and motivation (e.g., Bakker, 2005; Becker, Goetz, Morger, \& Ranellucci. 2014; Boekaerts, 2007; Cornelius-White, 2007; Davis, 2003; Frenzel, Goetz, Lüdtke, Pekrun, \& Sutton, 2009a; Radel, Sarrazin, Legrain, \& Wild, 2010; Rodrigo-Ruiz, 2016; Roorda, Koomen, Spilt, \& Oort, 2011; Vauras, Salonen, Lehtinen, \& Kinnunen, 2009) and social behavior, learning and performance (Becker et al., 2014; Beilock, Gunderson, Ramirez, \& Levine., 2010; Chernack, 2011; Cornelius-White, 2007; Furrer \& Skinner, 2003; Morris, Denham, Bassett, \& Curby, 2013; Rodrigo-Ruiz, 2016), and the operation of the school involved (e.g., Ashforth \& Kreiner, 2002; Frenzel, Goetz, Stephens, \& Jacob, 2009b). Considering the immediate and long-term implications that emotions have on well-being, learning and achievement, it is important to support adaptive emotions in teachers' professional life, and, therefore, emotions should be examined in any comprehensive discussion of teachers' motivation and behaviour (Becker et al., 2014; Chen, 2016; Frenzel et al., 2009b; Lambert, Mccarthy, O’Donnell, \& Wang, 2009; Stephanou, Gkavras, \& Doulkeridou, 2013). Furthermore, to fully understand and foster teachers' positive emotional experience at school, it is necessary to examine the antecedents of their emotions (see Becker, Keller, Goetz, Frenzel, \& Taxer 2015; Taxer \& Frenzel, 2015). However, there is a notable limited empirical research on teachers' emotions and their antecedents (Chen, 2016; Frenzel, 2014; Fried et al., 2015; Hargreaves, 2004; Keller, Woolfolk Hoy, Goetz, \& Frenzel, 2016; Pekrun \& Schutz, 2007; Sutton \& Wheatley, 2003).

Despite the wide variety of the antecedents of emotions, emotions are elicited by appraisals (Ellsworth \& Scherer, 2003; Zembylas, 2004). Also, despite the differences among the appraisal theorists of emotions, there is general agreement that, when an event happens, the individual concerned evaluates its significance on a number of criteria, such as its importance for one's self-identity and well-being, whether it is facilitator for or obstructs one's goals, and the ability to 
control and cope with it and its consequences (Efklides, 2006, 2011; Efklides, \& Volet, 2005; Frenzel, 2014; Pekrun, 2005; Pekrun, Frenzel, Goetz, \& Perry, 2007; Roseman \& Smith 2001; Sander, Grandjean, \& Scherer, 2005; Weiner, 1992, 2005). The estimated coping potential, especially, is crucial in further emotion differentiation, and in determining the appropriate response to the event by evaluating the resources at one's disposal (Lazarus, 1991; Schmidt, Tinti, Levine, \& Testa, 2010; Tong, \& Jia, 2017). Both efficacy beliefs and estimates of problem-solving ability are fundamental appraisals and resources into coping process, while lack of them is associated with more disengagement coping activities (Davis, DiStefano, \& Schutz, 2008; Heppner, Lee, Tian, 2009; Karademas \& Kalantzi-Azizi, 2004; Parto \& Besharat, 2011; Schutz \& Davis 2000; Warren \& Dowden, 2012). However, how teachers' self-and collective efficacy beliefs, and their subjectively perceived problem-solving ability affect their emotional experience at school have been hardly examined (see Betoret, 2006; Betoret \& Artiga, 2010; Frenzel, 2014; Stephanou et al., 2013), while both of them have been in the most studied in association to teachers stress and burnout (Betoret \& Artiga, 2010; Evers, Brouwers, \& Tomic, 2002; Skaalvik \& Skaalvik, 2010, 2016).

This study, based on previous empirical evidence relevant to teachers' emotions and Frenzel et al.'s (2009b) theoretical model about the antecedents and effects of teacher emotions, focuses on teacher emotions and the impact of efficacy beliefs and problem-solving appraisal on the emotions. To better understanding the specific antecedent factors that lead to teacher emotions, this investigation also expands upon previous research (see Betoret, 2006; Betoret \& Artiga, 2010; Fried et al., 2015; Rodrigo-Ruiz, 2016; Saric, 2015; Stephanou et al., 2013) by examining the role of the subjectively estimated ability in problem solving in the covariation effect of self-efficacy and collective-efficacy on emotions.

Finally, this study is interested in the role of teaching level in teachers' emotions and beliefs, since both set of concepts are context-related and socially-constructed (Adams \& Forsyth, 2006; Austin, 2012, 2013; Efklides \& Volet, 2005; Frijda, 2009; Hargreaves, 2000; Lazarus 2006; Takahashi, 2011; Tschannen-Moran \& Hoy, 2007), and primary school and high school are distinct contexts with certain and specific characteristics regarding organization and climate, the students they serve, and education of the staff (Hoy \& Miskel, 2008; Wolters \& Daugherty, 2007).

\subsection{Efficacy Beliefs}

Self-efficacy is a multidimensional construct with a powerful impact on how environmental opportunities and impediments are perceived, and, therefore, influences individuals' values, goals and behavior (Bandura, 2006; Schunk \& Meece, 2006; Zimmerman \& Cleary, 2006). Tschannen-Moran, Woolfolk Hoy and Hoy (1998), based on social cognitive theory (Bandura, 1986), define "teacher efficacy is the teacher's belief in his or her capability to organize and 
execute the courses of action required to successfully accomplish a specific teaching task in a particular context" (p. 232). Skaalvik and Skaalvik (2007: p. 612), in a similar way, defines it as "individual teachers' beliefs in their own ability to plan, organize, and carry out activities that are required to attain given educational goals." Accordantly, teachers' self-efficacy is a task-specific construct and reflects, for instance, the perceived available resources, obstacles and difficulty of the task, and constantly develops from their personal experiences (Bandura, 1986, 1997; Fives, 2003; Hoy \& Spero, 2005; Tschannen-Moran \& Hoy, 2007).

Teacher self-efficacy is an influential factor in the goals set, motivation in pursuing the goals, effort and resilience in front of the difficulties relevant to professional career (Bandura, 2006; Bandura \& Locke, 2003; Caprara, Barbarenelli, Steca, \& Malone, 2006; Coladarci, 1992; Fives, 2003; Locke \& Latham, 1990; Wolters \& Daugherty, 2007; Woolfolk \& Hoy, 1990). For instance, a strong sense of teacher self-efficacy predicts a significant advantage in initial task engagement, motivation and effort, job satisfaction, attrition, burnout, quality of instruction and classroom management (Avanzi, Miglioretti, Velasco, Balducci, Vecchio, Fraccaroli, \& Skaalvik, 2013; Brouwers \& Tomic, 2000; Collie, Shapka, \& Perry, 2012; Gilbert, Adesope, \& Schroeder, 2014; Holzberger, Philipp, \& Kunter, 2013; Jesus \& Lens, 2005; Klassen, Bong, Usher, Chong, Huan, Wong, \& Georgiou, 2009; Kulinna \& Cothran, 2003; Sariçam \& Sakiz, 2014; Skaalvik \& Skaalvik, 2014, 2016; Stephanou et al., 2013; Stephanou \& Mastora, 2013; Wolters \& Daugherty, 2007). Also, teachers' self-efficacy is a positive predictor of students' achievement (Ashton \& Webb, 1986; Caprara et al., 2006; Mohamadi \& Asadzadeh, 2012; Mojavezi \& Azad, 2012; Ross, 1992; Skaalvik \& Skaalvik, 2007), motivation (Mojavezi \& Azad, 2012; Ross, 1994; Tschannen-Moran \& Johnson, 2011) and self-efficacy (Anderson, Greene, \& Loewen, 1988).

Self-efficacy is not formulated in a vacuum, but it is a social construct in which the environment plays as much of a role as the belief in oneself (Bandura, 2001; Takahashi, 2011; Tschannen-Moran \& Barr, 2004). Furthermore, teachers' self-efficacy might not ensure success solely but interactively with their perceptions about the school, as a whole, capacity; that is the collective efficacy beliefs (Bandura, 1997; Goddard, LoGerfo, \& Hoy, 2004). Collective efficacy is "the perceptions of teachers in a school that the faculty as a whole can organize and execute the courses of action required to have a positive effect on students" (Hoy, Davis, \& Pape, 2006: p. 728). The perceived school collective-efficacy are the judgments about the ability of the school as a whole, not simply the sum of the efficacy beliefs of individual member, and it is a holistic assessment involving the collaborative and interactive group dynamics (see Fernández-Ballesteros, Díez-Nicolás, Caprara, Barbaranelli, \& Bandura, 2002). Therefore, to better understand teacher and school functions, it is of particular importance to examine teacher collective-efficacy beliefs.

In consistency with self-efficacy, empirical findings from various contexts, 
such as socio-police, work and school, demonstrate that the stronger the perceived collective efficacy, the stronger the persistency in front of impediments and difficulties, the higher the groups' aspirations, outcome expectations and motivation in pursuing the goals, the higher the resilience to stressors, and the greater the performance accomplishments (see Bandura, 2001; Caprara et al., 2003; Goddard et al., 2004; Hoy \& Miskel, 2008; Klassen \& Chiu, 2010; Klassen, Usher, \& Bong, 2010). Higher school collective-efficacy also enhances parent-teacher relationships, parental involvement and teacher innovation (Hoy \& Miskel, 2008; Klassen et al., 2010), and contributes into a work environment that builds teacher commitment to the school (Brinson \& Steiner, 2007). Also, school collective-efficacy positively impacts student achievement, particularly for children at risk (Bandura, 1993; Brinson \& Steiner, 2007; Goddard, Hoy, \& Woolfolk Hoy, 2000; Goddard et al., 2004; Ross, 1995, 1998; Ross, Hogaboam-Gray, \& Gray, 2003; Tschannen-Moran \& Barr, 2004; Woolfolk Hoy \& Davis, 2005).

Collective efficacy is not independent from "perceptions and actions of individuals within the social system" (Bandura, 2001: p. 14). More precisely, although self- and collective-efficacy are positively and bidirectionally related, "Collective efficacy is rooted in self-efficacy. Inveterate self-doubters are not easily forged into a collective efficacious force" (Bandura, 1982: p. 143). In line with this conception, Caprara, Barbarenelli, Borgogni, Petitta et al. (2003: p. 17) argue "The strong self-efficacy beliefs can lead a person to behave in ways that improve the performance of others in the system". Teachers' self-efficacy has proved a positive contributor of the perceived collective-efficacy (Demir, 2008; Stephanou et al., 2013). Consequently, in the present study, self-efficacy is expected to have a positive effect on collective-efficacy. The possible role of the problem-solving appraisal in the between them link is discussed next.

\subsection{Problem-Solving Appraisal, and its Association with Efficacy Beliefs}

Problem-solving is a complex construct, including cognitive, emotional and behavioral processes, aiming at defining adaptive responses to challenges or demands (D'Zurilla \& Nezu, 2010; Heppner, 2008; Heppner \& Krauskopf, 1987). These processes involve personal and environmental factors (see Heppner, Witty, \& Dixton, 2004; Zeidner \& Endler, 1996). Focusing on personal resource variables within the global person-environment conceptualizations of problem-solving and coping, how people appraise their problem-solving capabilities and whether they generally tend to approach or avoid the many life problems is of critical importance (D'Zurilla \& Nezu, 2010; Heppner et al., 2009). Problem-solving appraisal within the social problem-solving theory of D'Zurilla and colleagues is "as a generalized set of beliefs or expectancies about one's problem-solving abilities" and it differs from problem-solving skills (Heppner et al., 2004: p. 358). A widely accepted topic among many of the coping theories is the balance between the demands of the situation (or environment) and the abilities or resources of the person (e.g., D’Zurilla, 1986; Heppner \& Krauskopf, 1987; Lazarus, Delongis, 
Folkman, \& Gruen, 1985; Lazarus \& Folkman, 1984). For example, stress is experienced when an individual (teacher) lacks the capacity to meet objectively and subjectively appraised environmental demands. Overall, a critical resource for coping with life difficulties and challenges is the individual's problem-solving appraisal or general evaluation of oneself as a problem solver.

Past researches suggest a strong association between problem-solving appraisal and various coping activities, particularly problem-focused (see Chang, 2013; Folkman \& Lazarus, 1988). Effective problem solvers are adaptable and flexible, and they develop effective methods to solve the problems and achieve their goals, while ineffective problem solvers experience stress, and, often, result in psychological maladjustment (see Heppner et al., 2004). In academics, in at-risk academically group of students, problem-solving appraisal was related to important academic functioning and outcomes, such as course grades (Elliott, Godshall, Shrout, \& Witty, 1990), and the higher the positive appraisals of both problem-solving confidence and personal control the higher the academic grades (Blankstein, Flett, \& Watson, 1992). Similarly, teachers' perceptions of their ability in solving the problems positively influence the solution of the various problems relevant to their school (Betoret, 2006; Betoret \& Artiga 2010; Heppner \& Baker, 1997; Heppner, Cooper, Mulholland, \& Wei, 2001; Heppner \& Lee, 2002).

Recent research emphasizes the determinant role of self-efficacy in the process of problem solving and coping, since it influences whether or not the coping behavior starts, how much effort is expended and how long it endures (Karademas \& Kalantzi-Azizi, 2004; Knoll, Rieckmann, \& Schwarzer, 2005; Parto \& Besharat, 2011; Takaki, Nishi, Shimogama, Inada, Matsuyama, Kumano, \& Kuboki, 2003). More accurately, high self-efficacious individuals use more efficient ways of solving the problems because they trust their skills to handle difficult situations, and, consequently, they feel less negative emotions (Bandura, 1997; Betoret \& Artiga, 2010; Karademas \& Kalantzi-Azizi, 2004; Stetz, Stetz, \& Bliese, 2006). Also, individuals, who have high self-efficacy and feel they can control their life demands and challenges, tend to be better at solving their problems because they estimate the problem as a treatable condition through time allocation, effort and proper handling (Heppner \& Lee, 2002; Karademas \& Kalantzi-Azizi, 2004; Rotter, 1966; Stetz et al., 2006; Weiten, Dunn, \& Hammer, 2011). Teachers' self-efficacy is positively associated with the use of effective and proactive ways to handle problems, such as searching for social support, reflecting a positive perception of their problem-solving skills, and contributing into expectations of effective problem-solving and emotions of hope and confidence (Atik \& Erkan, 2009; Betoret \& Artiga, 2010; Chang, 2009; Chwalisz, Altmaier, \& Russell, 1992; Larson, Potenza, Wennstedt, \& Sailors, 1995).

On the contrary, an inefficient problem-solving appraisal reflects a negative approach to the problem which is associated with a doubt for problem-solving capabilities, inability to control personal behavior and emotions, and a tendency 
of problem avoidance (Heppner, 2008; Larson, Toulouse, Ngumba, Fitzpatrick, \& Heppner, 1994). A low sense of self-efficacy to deal with specific problems makes them a source of stress (Bandura, Taylor, Williams, Mefford, \& Barchas, 1985) and inactivation, resulting into a passive attitude or, even more, denial and self-blame (Bandura, 1997; Betoret \& Artiga, 2010; Terry, 1994). Also, people, who assess negatively their problem-solving capabilities, are characterized by indecision and less rational thought (Larson et al., 1994). Within the educational context, researches evident a tendency of teachers with low sense of self-efficacy to use avoidance strategies when they try to manage pedagogical barriers, such as class or student discipline problems (Beach \& Pearson, 1998; Betoret, 2006; Betoret \& Artiga, 2010; Lewis, 1999).

On the other hand, problem-solving appraisal might have an impact on collective-efficacy. While the role of problem-solving appraisal in shaping teachers' beliefs about their school efficacy has not been the topic of research, data from other social- and achievement-related situations evident that high problem solving appraisal is associated with sociability, cooperation, participation in social activities, openness and effectiveness in social and personal interactions because these individuals show a sensitivity to the needs and problems of others and they are willing to help, factors that foster a sense of collective efficacy (Battistich, Solomon, Watson, Solomon, \& Schaps, 1989; Betoret, 2006; Demir, 2008; D’Zurilla \& Nezu, 1999; Erozkan, 2013; Folkman, Lazarus, Dunkel-Schetter, DeLongis, \& Gruen, 1986). Teachers' involvement in school decisions and their willingness to work cooperatively enhance their sense of collective efficacy and contribute into effective solution of the school-related problems (Goddard, 2002; Louis \& Marks, 1998; Mawhinney, Haas, \& Wood, 2005; Ross et al., 2003).

\subsection{Emotions}

Fried et al. (2015: p. 427) define five distinct functions that teacher emotions involved in the learning-teaching process "information provision, giving quality to experience, influencing cognitive processes, regulating internal and external processes, and providing motivation". These functions operate in both intrapersonal and interpersonal level of the teacher. For example, teachers, who experience positive emotions, might generate more teaching ideas and strategies that might contribute in developing "broad minded coping" skills (Fredrickson, 2001: p. 223; Sutton \& Wheatley, 2003). These coping skills facilitate teachers to achieve their goals, such as teaching well and help students to learn. Also, teachers' positive emotions positively affect the students of various grade levels regarding motivation, achievement and social behavior in classes (Kunter, Tsai, Klusmann, Brunner, Krauss, \& Baumert, 2008; Turner, Meyer, Midgley, \& Patrick, 2003; Turner, Midgey, Meyer, Gheen, Anderman, \& Kang, 2002; Wentzel, 1996; Wong \& Dornbusch, 2000). In contrast, teachers' yelling influences harmful emotions of guilt, anguish, shame, and inferiority in students (Sutton \& 
Wheatley, 2003). In a similar way, teacher anxiety decreases student performance (Beilock et al., 2010; Saunders, 2013), and teachers, who demonstrate negative emotions and dissatisfaction in teaching, perform low instructional quality which leads to student disengagement (Postareff \& Lindblom-Ylänne, 2011). In addition, based on Pekrun, Goetz, Titz and Perry (2002) research for the effects of emotions upon learning, teachers' negative deactivating emotions, such as boredom, have a negative impact in the classroom, whereas their positive activating emotions, such as enjoyment, positively contribute in student learning. Furthermore, as Frenzel et al.'s (2009b) support, teachers' emotions that are impacted by student behaviors impact instruction which, in turn, influences student behaviors and achievement outcomes. For example, teachers, who are usually frustrated or sad by disruptive students or ineffective administration, are less intrinsically motivated, express a lack of enthusiasm for cultivating positive relationships with their students and report becoming tolerant, and less caring (Blase, 1986; Trigwell, 2012).

In teacher emotion literature, there is a limited evidence about the significance and the frequency of distinct emotions relevant to their professional duties, while there is agreement about the categorization of positive and negative emotions. Generally, research has shown that teachers experience a variety of emotions, such as enjoyment (Frenzel et al., 2009a; Sutton \& Wheatley, 2003), pride (Darby, 2008; Sutton \& Harper, 2009), anger and frustration (Chang, 2009; Kuppens, van Mechelen, \& Rijmen, 2008; Sutton, 2007), guilt (Hargreaves \& Tucker, 1991) and anxiety (Beilock et al., 2010; Keller, Chang et al., 2014), while being in the classroom. Hagenauer, Hascher and Volet (2015) found that teachers' emotions of joy, anger and anxiety are formulated by their interpersonal relationships with their students, classroom discipline and the student's engagement in classroom activities. Also, pleasure and satisfaction are experienced due to the perceived student progress, while, usually satisfaction is accompanied by pride (Shapiro, 2010; Stephanou \& Mastora, 2013; Sutton \& Wheatley, 2003). In addition, features of the school environment may be a positive or a negative contributor into the development of teachers' emotions (see Day \& Qing, 2009). For example, students' inactivity or unfriendliness provoke negative emotions in teachers (Kimura, 2010), and student misbehavior contributes into teachers' emotional exhaustion (Tsouloupas, Carson, Matthews, Grawitch, \& Barber, 2010).

Frenzel (2014), reviewing the literature, revealed the discrete emotions of enjoyment, pride, anger, anxiety, shame and guilt, boredom, and pity. Chen's (2016) research showed the emotions of joy, love, sadness, anger and fear, and argued that teachers might experience emotions that differ in nature. These differences might be related to high variety of professional duties as well as to specific situation that each research focuses, such as classroom teaching, interpersonal relationships teacher-student or teacher-colleagues and school-community link. As Stephanou et al. (2013) support, teachers may experience satisfaction, 
pride, enthusiasm, happiness and enjoyment for their good teaching, respectful relationships with their colleagues, warm school climate, and students' academic progress. In contrast, teachers may experience shame, hopelessness, anger, unhappiness and boredom for their unsuccessful teaching, negative relationships with their colleagues, undesirable school situations, and students' lack of academic progress.

Emotions influence teachers' cognition and beliefs, while the latter affect back into the emotions, underling that these concepts all exhibit complex interdependence (Gill \& Hardin, 2015). Teachers' emotional reactions to their students' or colleagues' various behaviors or to various events and situations happened at their school are mediated by appraisals. The most frequently referenced appraisals are valence, goal conduciveness, coping potential, accountability and goal significance (Ellsworth \& Scherer 2003; Lazarus, 1993; Roseman, 2001; Scherer, 2001; Zembylas, 2004), while Frenzel et al.'s (2009b) theoretical model of teacher emotions proposes conduciveness, goal importance, accountability and coping potential. Also, according to Pekrun's control-value theory of academic achievement emotions, value appraisals relate to the subjective importance of achievement related activities and outcomes, and control appraisals are action control expectancies, which refer to self-efficacy expectation, and action outcome expectancies that mean one's actions are perceived to lead to desired outcomes (see Pekrun, 2006; Pekrun et al., 2007). The next section focuses on the possible interactive impact of efficacy beliefs and problem-solving appraisal on teacher emotions.

\subsection{Effects of Efficacy Beliefs on Emotions}

There is a remarkable limited research on the association of teacher efficacy beliefs with their emotions, while there is indication of the between them link form other fields.

Previous studies in mental health and psychological adjustment show that self-efficacy beliefs are negatively related to the intensity of depressive symptoms and appear to have a beneficial link with mental and physical health contributing to peoples' well-being (Bandura, 1997; Endler, Kocovski, \& Macrodimitris, 2001; Jerusalem \& Hessling, 2009; Karademas \& Kalantzi-Azizi, 2004; O'Leary, 1992). Specifically, individuals with a low sense of self-efficacy magnify the severity of potential threats, worry about things that rarely happen, perceive their social environment as hostile, insist on their own deficiencies, and believe that they cannot control the threats, resulting into high anxiety, low functionality and high vulnerability to depression (Bandura, 1993; Fiori, McIlvane, Brown, \& Antonucci, 2006; Karademas \& Kalantzi-Azizi, 2004; Muris, 2002). Individuals also with low self-efficacy expectations are concomitant with a higher use of emotion-focused coping strategies, including denial and self-criticism (Terry, 1994), resulting in negative emotions.

In consistency with the just above mentioned general findings, lack of teacher 
self-efficacy can predict depression, stress, anxiety, burnout, and intention to leave the profession (Goddard \& Goddard, 2006; O’Neill \& Stephenson, 2012; Warren \& Dowden, 2012). The negative link between teachers' efficacy beliefs and burnout is most powerful in the two dimensions of emotional exhaustion and depersonalization (Aloe, Amo, \& Shanahan, 2014; Brown, 2012; Evers et al., 2002; Motallebzadeha, Ashraf, \& Yazdi, 2014; Skaalvik \& Skaalvik, 2010; Yu, Wang, Zhai, Dai, \& Yang, 2014). Warren and Dowden (2012), in addition, found a positive link between teachers' irrational beliefs and negative emotions.

A strong sense of self-efficacy and collective efficacy facilitates teachers to accomplish their own goals and their school goals, causing positive emotions (Caprara, Barbarenelli, Borgogni, Petitta et al., 2003; Goddard et al., 2000; Locke \& Latham, 1990; Pekrun, 2006; Stephanou et al., 2013; Wolters \& Daugherty, 2007). In a similar way, teachers with high sense of self-efficacy help their students to control threatening situations and, therefore, experience lower stress and more positive emotions (Bandura, 1993; Betoret \& Artiga, 2010; Greenwood, Olejnik, \& Parkay, 1990; Schwarzer \& Hallum, 2008; Vaezi \& Fallah, 2011). In contrast, teachers' sense of inability to fulfill their duties or satisfy their students' needs contributes into emotions of guilty and shame (Hargreaves, 2001; Hargreaves \& Tucker, 1991).

According to a few previous studies, teachers' efficacy beliefs are associated positively with positive emotions and negatively with negative emotions relevant to their professional duties (see Brígido, Borrachero, Bermejo, \& Mellado, 2013; Pitkäniemi, 2017; Salanova, Cifre, Grau, Llorens, \& Martínez, 2005; Stephanou et al., 2013), although, in rare cases, efficacy beliefs positively relate to negative emotions (Brígido et al., 2013). Stephanou et al. (2013), for example, revealed that teachers' self-efficacy predicts general- and context-related emotions, such as happiness, pleasure, low irritation and low boredom, reflecting the high efficacious teachers' enjoyment experienced from task-involvement and their ability in controlling their environment (Bandura, 1997; Pekrun, 2006; Pekrun, Goetz, Daniels, Stupnisky, \& Perry, 2010; Ross, 1994). They also, basing on earlier studies (e.g., Pekrun, 2006; Ross, Cousins, \& Gadalla, 1996; Weiner, 2005), argued that teachers' efficacy influences expectancy dependent-emotions, such as hope and optimism, in addition to competitive dependent-emotions, such as competence, since, although personal abilities judgments are shaped by past experiences, self-efficacy beliefs are future-oriented, representing the belief for future success (Bandura, 1997; Bong \& Skaalvik, 2003; Skaalvik \& Bong, 2003; Tschannen-Moran \& Johnson, 2011).

In a similar way, although very few studies have examined the link between collective efficacy and experienced emotions in school, there is evidence that, like self-efficacy, collective efficacy has a positive impact on the achievement-related emotions (see Klassen et al., 2010). For example, Stephanou et al. (2013) found that teachers' collective efficacy beliefs contributed in the formation of the emotions of encouragement, low irritation and happiness, underlin- 
ing the important role of the context and the sense of school effort in shaping teachers' positive emotions. However, teachers' collective efficacy is expected to have indirect effects on their experienced emotions at school through self-efficacy, particularly on the self-related emotions, because, as above discussed, it is influenced by self-efficacy.

\subsection{Effects of Problem-Solving Appraisal on Emotions}

As above mentioned, coping potential, which refers to appraisals about the strength of one's personal control over events and actions, is a central appraisal of emotions. Despite the limited research in education context, the existence literature supports that problem-solving appraisal is a significant source of coping procedure that implies emotional response to an event.

Individual's appraisal of his/her problem-solving ability affects problem-solving performance, the whole problem-solving process and the followed emotions. On the other hand, the emotions arising from a successful or unsuccessful effort to solve a problem enhance or undermine further the performers' perceptions of their capabilities in problem-solving. For example, positive emotions and positive emotional states for a successful problem solution have a multitude of facilitative effects, such as increase of creativity, enhancement of flexibility and a wider "thought-action repertoire" that, in turn, facilitate problem-solving (see Cohen, Pham, \& Andrade 2008; Fredrickson, 2001; Fredrickson \& Branigan, 2005; Isen, 2001, 2008). When teachers, specifically, experience positive emotions, apply a wide variety of teaching strategies that lead to goal achievement and more intense positive emotions (Fredrickson, 2001; Sutton \& Wheatley, 2003). Conversely, the teachers' high stress and negative emotions harm their concentration, extend their disturbing thoughts and concerns, and, finally, prevent the solution of various problems within a classroom (Beach \& Pearson, 1998; Emmer, 1994; Sutton \& Wheatley, 2003).

Problem-solving appraisal has been found to relate to a wide range of cognitive responses, including expectations, attributions, and negative self-statements (Heppner et al., 2004), all of which influence emotions, in favoring the self-appraised effective problem solvers. For example, as Baumgardner, Heppner and Arkin (1986) revealed, perceived ineffective problem solvers did not differ in their attributions for success or failure feedback, whereas the self-appraised effective problem solvers attributed success than failure to more ability and effort. Similar were the findings by Larson et al. (1995) and Larson and Sailors (1997) with respect teachers' handling classroom disruptions, while delivering a 15-minute classroom presentation. Also, individuals, who estimate their problem-solving ability as inadequate, tend to perceive the interpersonal problems as unchangeable and use more task-inhibiting self-statements, more emotion- and self- than problem-focused statements (Mayo \& Tanaka-Matsumi, 1996). In contrast, perceived effective problem solvers expect themselves to be more successful, accept personal responsibility for personal problems and insist in prob- 
lem solving, resulting in positive outcomes (see Heppner et al., 2004).

Consistent with the just above mentioned, a positive problem-solving appraisal is related to higher levels of social support, as well as friends who tend to have a positive problem-solving appraisal (Elliott, Godshall, Herrick, Witty, \& Spruell, 1991; Elliott, Herrick, \&Witty, 1992; Wang, Heppner, \& Berry, 1997; Wright \& Heppner, 1991). Moreover, the self-perceived ineffective problem solvers tend to consider their significant others more negatively (Larson, Allen, Imao, \& Piersel, 1993). Teachers might perceive their colleagues and their school administrators negatively, followed by negative emotions, since under such situations individuals experience negative emotions.

Also, some researchers have examined the correlation of problem-solving to mental health and psychological adjustment, since inadequate problem-solving abilities have been associated with stress, depression, maladaptive behavior and physical health symptoms (see Heppner, Witty, \& Dixon, 2004; Largo-Wight, Peterson, \& Chen, 2005). An individual's positive appraisal of his/her problem-solving skills is associated with psychological adaptability and functionality, and it facilitates the solutions for the challenges of everyday life (Endler, Kovovski, \& Macrodimitris, 2001; Heppner, 2008; Summerfeldt \& Endler, 1996; Zeidner \& Endrler, 1996). Conversely, individuals, who estimate themselves as ineffective problem solves, are less able to adequately respond to problems, deal less effectively with others in their environment, experience high depression, anxiety and anger, are low in self-esteem and have a tendency to avoid problems (Carscaddon, Poston, \& Sachs, 1988; Heppner et al., 2001; Heppner, Pretorious, Wei, Lee, \& Wang, 2002; Lazarus \& Folkman, 1984; Pretorius \& Diedricks, 1994; Sabourin, Laporte, \& Wright, 1990; Sahin, Sahin, \& Heppner, 1993). Avoidance to problems, in particular, is associated with limited chances to develop robust confidence in dealing effectively with problems, resulting in depression, anger, loneliness and maladative psychosocial adjustment (Heppner, Lee, Wei, Anderson, \& Wang, 2001; Witty, Heppner, Bernard, \& Thoreson, 2001). In addition, self-perceived ineffective problem solvers reported more occupational burnout (Elliott, Shewchuk, Hagglund, Rybarczyk, \& Harkins, 1996) and discomfort (Larson et al., 1994), emotion-focused coping strategies (MacNair \& Elliott, 1992), emotional arousal and intense negative affect during problem solving (Larson et al., 1995) and self-focused as opposed to problem-focused statements (Mayo \& Tanaka-Matsumi, 1996), and less awareness of the problem-solving process (Larson et al., 1995). The relationship between emotions and problem-solving has been studied in relation to stress and burnout of teachers, demonstrating a negative link (see Betoret, 2006; Betoret \& Artiga, 2010; Chang, 2009; Lewis, 1999).

\subsection{Aim and Hypotheses of the Study}

This study aimed to examine: 1) teachers' experienced emotions at school, perceptions of their ability in problem-solving, self-efficacy and school collective-efficacy 
beliefs; 2) the role of self-efficacy in the formulation of school collective-efficacy and problem-solving appraisal, and in the effect of problem-solving appraisal on school collective-efficacy; 3) the interactive impact of self-efficacy, school collective-efficacy and problem-solving appraisal on the emotions; and 4) the role of teaching level (primary/junior high school) in the examined concepts.

The hypotheses of this research were the following:

The teachers from both teaching levels will report a rate of school collective-efficacy and self-efficacy but no specific hypothesis is stated about a certain rate of each of the two variables (Hypothesis 1a). Primary school teachers, in comparison to junior high school teachers, will estimate their self-efficacy and school collective-efficacy higher (Hypothesis 1b).

The participants will estimate their problem-solving ability in daily life problems but no hypothesis is tested about a specific rate of it (Hypothesis 2a). There will be differences among the components of problem-solving appraisal in least favoring personal control (Hypothesis 2b). No certain hypothesis is tested about the association of the teaching level with problem-solving appraisal (Hypothesis 2c).

The teachers will experience various emotions (mainly, context- and task-related) at school but no specific hypothesis is examined about the extent of the intensity of each of the emotions (Hypothesis 3a). The primary school teachers, compared to junior high school teachers, will report positive emotions more intensely (Hypothesis 3b).

Self-efficacy will be an influential determinant of collective-efficacy (Hypothesis $4 \mathrm{a}$ ) and problem-solving appraisal, with its predictive power to vary across the components of the perceived problem-solving ability, in favoring confidence (Hypothesis $4 \mathrm{~b}$ ). Self-efficacy will enhance the effect of problem-solving appraisal on collective-efficacy (Hypothesis 4c).

Self-efficacy, perceived school collective-efficacy and problem-solving appraisal, independently, and, as a group, will be a positive formulator of the experienced emotions at school, mainly the self-, context- and both task- and future-related emotions respectively (Hypothesis 5a). Problem-solving appraisal will be a positive influential factor of the effect of collective-efficacy on the emotions (Hypothesis 5b). Self-efficacy will positively influence the impact of collective-efficacy and problem-solving appraisal on emotions, particularly the self-related emotions (Hypothesis 5b).

\section{Method}

\subsection{Participants}

The sample comprised 256 teachers, 92 men and 164 women, of whom 131 recruited from 30 primary schools and 125 from 35 junior high schools, from various regions of Greece, representing a variety of Greek state school contexts. The participants came through stratified random sampling, and they reported teaching experience from 2 to 28 years with balance among years of teaching expe- 
rience, and their age ranged from 24 to 58 years, with mean age of 46 years.

\subsection{Measures}

\subsubsection{Emotions}

The teachers' experienced emotions at school were estimated by reporting the extent to which they usually experience each of the eighteen emotions during the current school year. The scale consisted of the emotions of happiness, satisfaction, pleasure, pride, encouragement, confidence, calmness, anger, flow, cheerfulness, exciting, irritation, hope, competence, nervousness, anxiety, enthusiasm and boredom. The emotions were in the form of adjective, with two opposite poles: the positive pole having the high score of 7 and the negative pole having the low score of 1 (e.g., pleased 7654321 unpleased). The scale was constructed in consistency with previous researches that had examined similar topic (see Pekrun \& Bühner, 2014; Pekrun, Goetz, Frenzel, Barchfeld, \& Perry, 2011; Schutz \& DeCuir, 2002; Stephanou \& Mastora, 2013; Stephanou et al., 2013). This scale, in addition, is a valid and reliable measure in examining emotions in education in Greek population (see Stephanou, 2011; Stephanou, Kariotoglou, \& Ntinas, 2011; Stephanou et al., 2013). In the present study, Cronbach's alpha was .92 .

\subsubsection{Efficacy Beliefs}

The participants' self-efficacy beliefs and school collective-efficacy beliefs were examined by a respective subscale that came from Caprara et al.'s (2003) questionnaire. The self-efficacy subscale contains twelve items referring to teachers' beliefs in their ability to handle effectively various tasks, obligations and challenges that are related to their professional role. The collective efficacy subscale consists of nine items concerning teachers' perceptions about the school capability in handling effectively various challenges, difficulties and demands that are associated with its institutional role. The teachers were asked to indicate the extent of their agreement with each of the items, ranging from $1=$ strongly disagree to $7=$ strongly agree, with the highest score to declare a positive estimation of efficacy. Both subscales are reliable and valid research instruments in Greek population (see Stephanou et al., 2013). In this study, Cronbach's alpha value was .88 . and .93 for self-efficacy and collective efficacy respectively.

\subsubsection{Problem-Solving Appraisal}

Teachers' perceptions about their ability in problem-solving were estimated via the Problem Solving Inventory (PSI, Heppner \& Baker, 1997; Heppner \& Petersen, 1982). The PSI contains 35, 6-point, items, measuring the individual's perceptions about his/her problem-solving ability and problem-solving style in the everyday life. Accurately, the PSI estimate one's 1) Problem-Solving Confidence (PSC, 11 items) which is associated with confidence, belief and self-assurance in effectively solving problems, 2) Approach-Avoidance style (AAS, 16 items) regarding the tendency of avoidance or approaching the problem, and 3) Personal 
control (PC, 5 items) on behavior and emotions. The smaller the score in each of the subscales the higher the individual's functioning in problem-solving.

Two Greek native language speakers, who were fluent in the English language, translated the PSI from English language into Greek language independently, while the Greek version was translated into the origin language by another translator. Then, a new version of the scale came by making modifications in the discrepancies in the four versions of the PSI. This final version, afterwards, were given to a small group of ten teachers to further estimate the suitability of the scale which was positively perceived.

In this research, five factors were found, explaining $65 \%$ of the total variance of problem-solving appraisal: Personal control in problem-solving, Problem-Solving Confidence, Reflective/Approach, Monitoring style and Impulsive style. The values of Cronbach's alphas were acceptable, ranging from .67 for personal control through .73 for confidence, .75 for monitoring, .79 for impulsive to .82 for reflective/approach.

\subsubsection{Personal Factors}

A short set of questions examined the participants' demographical and personal factors, such as gender, teaching level, age and teaching experience.

\subsection{Procedure}

Prior to administering the scales, permission to participate was obtained from each participating school. The teachers were received written information about the aim of this investigation, and they were assured of anonymity and confidentiality. The participants were asked to use a code name on all the scales to match the questionnaires that were filled by the same teacher. The teachers completed the scales individually in a quite classroom, in front of the researches, in their own free time in school. In order to be adequate time for the participants to form an impression about the examined concepts, data were collected at the middle of a school year. Also, to ensure that any relation among the examined variables was not due to the procedure, the teachers completed, first, the emotions scale, then the collective-efficacy scale, followed by the PSI, and, finally, the self-efficacy scale.

\section{Results}

\subsection{Efficacy Beliefs}

The results from Anovas with teaching level as between-subjects factor and the type of teachers' efficacy beliefs as dependent variable revealed no significant effect in self-efficacy, $\mathrm{F}(1,254)=1.97, p>.05$., showing that the primary school teachers $($ Mean $=5.73, \mathrm{SD}=.84)$ and the junior high school teachers (Mean = $5.58, \mathrm{SD}=.87)$ estimated it in a similar way, while, in contrast, there was a significant effect on the perceived school collective-efficacy, $\mathrm{F}(1,254)=5.95, p$ $<.01$, indicating that the primary school teachers (Mean $=5.49, \mathrm{SD}=1.10$ ), in 
comparison to secondary schools teachers (Mean $=5.10, \mathrm{SD}=1.21$ ), perceived their school as more effective in its institutional role. In addition, the mean scores support that, in both groups of the teachers, collective- and self-efficacy beliefs ranged from moderate to high. The $\sigma \varepsilon$ findings totally and partly confirmed Hypothesis 1a and Hypothesis $1 \mathrm{~b}$ respectively.

\subsection{Problem-Solving Appraisal}

The results from the two repeated measures ANOVAs, one for each group of teachers in which the five components of the problem-solving appraisal was the within-subjects factor, showed significant effect in the group of primary school teachers, $\mathrm{F}(4,127)=26.59 p<.01, \mathrm{n}^{2}=.46$, and in the group of junior high school teachers, $\mathrm{F}(4,121)=15.23, p<.01, \mathrm{n}^{2}=.34$. Post hoc pairwise comparisons and the mean scores (Table 1 ) within each teaching level revealed that in both groups of teachers the components of problem-solving appraisal were estimated in the following order from most to least: Monitoring style, impulsive style, confidence, reflective, personal control. Also, inspection of the mean scores in Table 1 indicates that the teachers ranged all the components of their problem-solving ability from moderate to high, expect personal control in primary education which was perceived as low to moderate.

The results from Anovas with the teaching level of the participants (primary/secondary education) as between-subjects factor and each of the five components of problem-solving appraisal as dependent variable showed significant effects. The findings from Discriminant analysis (Wilks' Lambda criterion), with stepwise method, confirming the Anovas results, revealed that personal control in problem-solving, Cohen's $d=.26$, discriminating power $=.64$, followed by impulsive style in problem-solving, Cohen's $\mathrm{d}=-.11$, discriminating power $=$ -.30, was the most powerful factor in discriminating the two groups of teachers (Table 1). Specifically, the junior high school teachers, compared to primary school teachers, had the sense that they had higher personal control in daily problem-solving, while the primary school teachers estimated themselves as less impulsive in the daily problem-solving process than the junior high school teachers did.

The above results were in the most consistent with the Hypotheses $2 \mathrm{a}, 2 \mathrm{~b}$ and $2 \mathrm{c}$.

Table 1. Results from Discriminant Function analysis for the effect of teaching level (primary/junior high school) on teachers' components of problem-solving appraisal.

\begin{tabular}{ccccccccc}
\hline \multicolumn{7}{c}{ Primary School } & \multicolumn{7}{c}{ Junior High School } \\
\hline & Mean & SD & Mean & SD & Wilks' Lambda F & $(1,254)$ & Discriminating power Cohen's d \\
\hline Confidence & 2.44 & .76 & 2.45 & .78 & 1 & .04 & .14 & .01 \\
Reflective & 2.51 & 1.08 & 2.52 & .99 & 1 & .10 & -.02 & .06 \\
Monitoring & 2.13 & .92 & 2.08 & .88 & .99 & .16 & .06 \\
Impulsive & 2.27 & 1.03 & 2.38 & 1.10 & .99 & 2.00 & -.30 & -.11 \\
Personal control & 3.02 & 1.03 & 2.75 & 1.08 & .98 & 4.10 & .64 & .26 \\
\hline
\end{tabular}

Note: $\mathrm{F}(1,254)=4.10, p<.01 ; \mathrm{F}(1,254)=2.00, p<.05 ; \mathrm{F}(1,254)<2.00, p>.05$. 


\subsection{Emotions}

The findings from the repeated measures ANOVAs, one for each group of teachers, in which emotions was the within-subjects factor, revealed that the teachers reported an experience of a variety of intensity of emotions at school over the school year, in primary education, $\mathrm{F}(17,114)=5.79, p<.01, \mathrm{n}^{2}=.46$, and in junior high school, $\mathrm{F}(17,108)=6.76, p<.01, \mathrm{n}^{2}=.52$. Inspection of the scores in Table 2 and post hoc pairwise comparisons indicate that the teachers, in both groups, experienced from moderate to low intensity of negative emotions, and from moderate to high intensity of positive emotions. Precisely, in the group of primary school teachers, in comparison to the rest of the emotions, exciting, no boredom, competence and flow were the most intense positive emotions, while discouragement and anxiety were the most intense negative emotions. The findings regarding the junior high school teachers revealed that the most intense positive emotions were no boredom, competence, exciting and flow, while the most intense negative emotions were discouragement, nonconfidence, irritation and hopelessness.

The results from Anovas, with the two groups of teachers as between-subjects

Table 2. Results from discriminant function analysis for the effect of teaching level (primary/junior high school) on teachers' emotions.

\begin{tabular}{|c|c|c|c|c|c|c|c|c|}
\hline \multirow[b]{2}{*}{ Emotions } & \multicolumn{2}{|c|}{ Primary School } & \multicolumn{2}{|c|}{ Junior High School } & \multirow{2}{*}{ Wilks' Lambda } & \multirow{2}{*}{$\mathrm{F}(1,254)$} & \multirow{2}{*}{ Discriminating power } & \multirow{2}{*}{ Cohen's d } \\
\hline & Mean & SD & Mean & SD & & & & \\
\hline Happiness & 5.37 & 1.10 & 5.35 & 1.18 & 1.00 & .01 & .10 & .02 \\
\hline Satisfaction & 5.34 & 1.15 & 5.24 & 1.41 & .99 & .36 & .11 & .08 \\
\hline Pleasure & 5.40 & 1.16 & 5.22 & 1.41 & .99 & 1.15 & .16 & .14 \\
\hline Pride & 5.29 & 1.30 & 5.12 & 1.38 & .99 & 1.03 & .14 & .13 \\
\hline Encouragement & 4.89 & 1.37 & 4.54 & 1.44 & .98 & 3.95 & .23 & .25 \\
\hline Confidence & 5.18 & 1.34 & 4.84 & 1.57 & .98 & 3.39 & .37 & .24 \\
\hline Calmness & 5.11 & 1.30 & 5.02 & 1.50 & .99 & .27 & .09 & .06 \\
\hline Anger & 5.43 & 1.20 & 5.49 & 1.35 & .99 & .14 & .03 & -.05 \\
\hline Flow & 5.65 & 1.16 & 5.50 & 1.23 & .99 & 1.05 & .16 & .13 \\
\hline Cheerfulness & 5.47 & 1.11 & 5.31 & 1.35 & .99 & 1.00 & .14 & .13 \\
\hline Exciting & 5.70 & 1.19 & 5.50 & 1.19 & .99 & 1.78 & .16 & .17 \\
\hline Irritation & 5.25 & 1.48 & 4.86 & 1.70 & .98 & 3.80 & .33 & .24 \\
\hline Hope & 5.27 & 1.28 & 4.90 & 1.43 & .98 & 4.59 & $.55^{*}$ & .27 \\
\hline Competence & 5.66 & 1.16 & 5.53 & 1.20 & .99 & .76 & .09 & .11 \\
\hline Nervousness & 5.27 & 1.27 & 5.29 & 1.28 & 1.00 & .01 & -.12 & -.02 \\
\hline Anxiety & 4.89 & 1.43 & 5.20 & 1.38 & .98 & 3.06 & $-.44^{*}$ & -.22 \\
\hline Enthusiasm & 5.16 & 1.18 & 5.02 & 1.35 & .99 & .75 & .06 & .11 \\
\hline Boredom & 5.69 & 1.20 & 5.69 & 1.15 & 1.00 & .00 & .09 & .00 \\
\hline
\end{tabular}

Note: $\mathrm{F}(1,254)>3.06, p<.05 ; \mathrm{F}(1,254)<1.78, p>.05 ;{ }^{*}$ : Emotions that uniquely contributed into discrimination of the two groups of teachers. 
factor and each of the emotions as dependent variable, showed significant effect of the teaching level on the emotions of encouragement, $\mathrm{F}(1,254)=3.95, p$ $<.05$, confidence, $\mathrm{F}(1,254)=3.40, p<.05$, hope, $\mathrm{F}(1,254)=4.59, p<.05$, irritation $\mathrm{F}(1,254)=3.80, p<.05$, and anxiety, $\mathrm{F}(1,254)=3.06, p<.05$. More accurately, the descriptive statistics in Table 2 show that the primary school teachers, compared to junior high school teachers, experienced these emotions more positively, with the exception being in the emotion of anxiety that was more intense in primary school teachers.

Discriminant analysis, with stepwise method, was conducted to determine the set of emotions that best discriminated the two groups of teachers (Table 2). The results from the analysis confirmed the findings from the Anovas, and, in addition, revealed that only the emotion of hope, Cohen's $d=.27$, discriminating power $=.55$, followed by the emotion of anxiety, Cohen's $d=-.22$, discriminating power $=-.44$, uniquely contributed into discriminating the group of primary school teachers from the group of junior high school teachers. The rest of the emotions had no significant contribution in discriminating the two groups of teachers.

These results partially confirmed Hypotheses $3 \mathrm{a}$ and $3 \mathrm{~b}$.

\subsection{Inter-Effects of Efficacy Beliefs and Problem-Solving Appraisal on Emotions}

Prior to main analyses for the inter-effects of the examined variables, correlation coefficient analyses (Table 3 ) were conducted among teachers' efficacy-beliefs, problem-solving appraisal and emotions, separately for each teaching level.

\subsubsection{Effects of Self-Efficacy on Collective-Efficacy and Problem-Solving Appraisal}

Confirming Hypothesis 4a, the results from correlation coefficient analyses (Table 3) and bivariate regression analyses, separately in each group of teachers, showed that higher self-efficacy was correlated with higher school collective efficacy, in the group of primary school teachers, explaining $55 \%$ of the variance, $\mathrm{F}$ $(1,129)=155.03, p<.01$, beta $=.74, \mathrm{t}=12.45, p<.01$, and in junior high school teachers, accounting for $46 \%$ in the variance, $\mathrm{F}(1,123)=105.93, \mathrm{p}<.01$, beta $=.68, \mathrm{t}=10.00, p<.01$.

The results from correlation coefficient analyses (Table 3 ) and a series of bivariate regression analyses (Table 4) in which self-efficacy beliefs was the predictive variable and each of the components of problem-solving appraisal was the predicted variable, within each group of teachers, revealed that, while self-efficacy accounted in the variance in problem-solving appraisal, its influential power varied across the components of problem-solving and within each group of teachers. More accurately, the findings are the following.

In the primary school teachers, self-efficacy: 1) had negative effect on the components of problem-solving appraisal, indicating that the high self-efficacious teachers had high confidence in their problem-solving ability, high monitoring, 
reflective, personal control and impulsive styles in problem-solving, 2) explained from a small to moderate amount of the variance in problem-solving, $R^{2}$

Table 3. Relations among teachers' self-efficacy, school collective-efficacy, components of problem-solving appraisal and emotions in association to teaching level (primary/junior high school).

\begin{tabular}{|c|c|c|c|c|c|c|c|c|c|c|c|c|c|c|}
\hline & \multicolumn{2}{|c|}{ Self-efficacy } & \multicolumn{2}{|c|}{ Collective-efficacy } & \multicolumn{2}{|c|}{ Confidence } & \multicolumn{2}{|c|}{ Reflective } & \multicolumn{2}{|c|}{ Monitoring } & \multicolumn{2}{|c|}{ Impulsive } & \multicolumn{2}{|c|}{ Personal control } \\
\hline & PS & JHS & PS & JHS & PS & JHS & PS & JHS & PS & JHS & PS & JHS & PS & JHS \\
\hline Happiness & .48 & .57 & .39 & .52 & - & - & - & - & - & -.20 & - & - & - & - \\
\hline Satisfaction & .58 & .55 & .58 & .49 & -.25 & _ & -.21 & - & -.24 & - & - & - & - & - \\
\hline Pleasure & .55 & .53 & .55 & .51 & -.20 & - & - & -.20 & - & -.19 & - & - & - & - \\
\hline Pride & .58 & .57 & .44 & .52 & -.23 & - & -.21 & -.22 & - & - & - & - & - & - \\
\hline Encouragement & .54 & .51 & .54 & .53 & -.23 & - & -.23 & - & - & - & - & -.20 & - & - \\
\hline Confidence & .53 & .41 & .49 & .41 & - & - & -.20 & - & - & - & - & -.20 & - & - \\
\hline Calmness & .47 & .45 & .48 & .35 & -.29 & -.19 & _ & -.19 & _- & -.21 & _- & -.34 & _- & -.33 \\
\hline Anger & .60 & .33 & .51 & $.18^{*}$ & -.32 & -.20 & -.20 & - & -.19 & -.18 & - & -.26 & - & -.29 \\
\hline Flow & .48 & .38 & .45 & .39 & - & - & - & -.23 & -.22 & -.26 & - & -.22 & - & - \\
\hline Cheerfulness & .58 & .54 & .52 & .49 & -.21 & - & -.19 & -.19 & - & -.24 & - & -.18 & - & - \\
\hline Excitement & .49 & .46 & .45 & .32 & - & -.19 & - & -.20 & -.25 & -.20 & - & -.24 & - & -.19 \\
\hline Irritation & .51 & .35 & .53 & .45 & -.21 & - & - & -.18 & - & - & - & -.24 & - & - \\
\hline Hope & .47 & .49 & .47 & .45 & -.24 & - & - & - & - & - & - & -.21 & - & -.20 \\
\hline Competence & .51 & .44 & .32 & .29 & -.17 & -.27 & - & -.21 & -.21 & - & - & - & - & -.18 \\
\hline Nervousness & .65 & .47 & .52 & .36 & -.35 & -.22 & - & - & -.19 & - & -.20 & - & - & - \\
\hline Anxiety & .52 & .60 & .41 & .34 & -.34 & -.27 & _- & _ & _- & _- & -.20 & _- & _- & -.23 \\
\hline Enthusiasm & .51 & .55 & .44 & .52 & -.21 & - & -.26 & - & - & - & - & - & - & - \\
\hline Boredom & .45 & .52 & .40 & .34 & - & - & -.17 & - & -.19 & - & - & -.25 & - & -.30 \\
\hline Self-efficacy & 1.00 & 1.00 & .74 & .68 & -.44 & -.35 & -.27 & -.28 & -.40 & -.31 & -.22 & -.28 & -.19 & -.32 \\
\hline Collective-efficacy & .74 & .68 & 1.00 & 1.00 & -.28 & _- & -.19 & -.24 & -.27 & -.27 & _ & _ & _ & _- \\
\hline
\end{tabular}

Note: PS: Primary School; JHS: Junior High School; r-values $<.22, p<.05$; r-values $>.22, p<.01$; -: r-values are not significant at the level of.05 level of significance.

Table 4. Results from bivariate regression analyses for the impact of teachers' self-efficacy on the components of problem-solving appraisal in association to teaching level (primary/junior high school).

\begin{tabular}{|c|c|c|c|c|c|c|c|c|}
\hline & \multicolumn{4}{|c|}{ Primary school } & \multicolumn{3}{|c|}{ Junior High School } & \multirow{2}{*}{$\mathrm{t}$} \\
\hline & $\mathrm{R}^{2}$ & $\mathrm{~F}(1,129)$ & beta & $\mathrm{t}$ & $\mathrm{R}^{2}$ & $\mathrm{~F}(1,123)$ & beta & \\
\hline Confidence & .20 & 31.35 & -.44 & -5.60 & .12 & 17.30 & -.35 & -4.16 \\
\hline Monitoring & .16 & 24.72 & -.40 & -4.97 & .10 & 12.78 & -.31 & -3.57 \\
\hline Reflective & .07 & 10.34 & -.27 & -3.22 & .08 & 10.58 & -.32 & -3.72 \\
\hline Impulsive & .05 & 6.38 & -.22 & -2.53 & .08 & 10.47 & -.28 & -3.24 \\
\hline Personal control & .04 & 4.66 & -.19 & -2.16 & .10 & 13.87 & -.32 & -3.72 \\
\hline
\end{tabular}

Note: $\mathrm{F}=4.66, p<.05 ; \mathrm{F}>6.38, p<.01 ; \mathrm{t}=-2.16, p<.05 ; \mathrm{t}>-2.53, p<.01$. 
ranged from .05 to .20 , and 3) mainly accounted in the variance in confidence in problem-solving, $\mathrm{R}^{2}=.20$, and monitoring style, $\mathrm{R}^{2}=.15$.

In junior high school teachers, self-efficacy: 1) negatively influenced problem-solving appraisal, showing that the higher the self-efficacy was, the greater the confidence, personal control, monitor, reflective and impulsive in problem-solving were, 2) explained a low amount of the variability of the elements of problem-solving, $\mathrm{R}^{2}$ ranged from .08 to .10 , and 3 ) was a better predictor of confidence in problem-solving, $\mathrm{R}^{2}=.12$, and both personal control and monitoring style, $\mathrm{R}^{2}=.10$, than of the rest of the constructs of problem-solving appraisal.

Hypothesis $4 \mathrm{~b}$ was partly confirmed by the above results.

\subsubsection{Effects of Self-Efficacy on the Impact of Problem-Solving Appraisal on Collective-Efficacy}

Observation on the results from correlation coefficient analyses in Table 3 indicates that the primary school teachers with high reflective style, and, mainly, with high confidence in their ability and strategizing how to approach a problem, by monitoring, perceived their school-efficacy highly. In a similar way, as expected, the secondary school teachers who felt effective problem solvers with respect to reflective, and, in particularly monitoring style, estimated their school more effective in its institutional role. However, unexpectedly, in both groups of teachers, there were no associations between collective-efficacy and both personal control and impulsive style of problem-solving.

In addition, hierarchical regression analysis (Table 5), separately for primary

Table 5. Results from hierarchical regression analyses for the role of teachers' self-efficacy in the impact of problem-solving appraisal on collective-efficacy in association to teaching level (primary/junior high school).

\begin{tabular}{|c|c|c|c|c|c|c|c|}
\hline & Steps & $\mathbf{R}^{2}$ & $\mathrm{R}^{2} \mathrm{ch}$ & $F(d f)$ & $\operatorname{Fch}(\mathrm{df})$ & beta & $\mathrm{t}$ \\
\hline \multicolumn{8}{|l|}{ Primary School } \\
\hline Confidence & & & & & & -.18 & -1.64 \\
\hline Monitoring & $1^{\mathrm{st}}$ & .10 & & $4.66(3,127)$ & & -.17 & -1.72 \\
\hline Reflective & & & & & & -.03 & -.25 \\
\hline Confidence & & & & & & .07 & .85 \\
\hline Monitoring & & & & & & .01 & .13 \\
\hline Reflective & 2 & .55 & & $38.38(4,126)$ & & -.02 & -.21 \\
\hline Self-efficacy & & & .45 & & $125.79(1,126)$ & .77 & 11.22 \\
\hline \multicolumn{8}{|c|}{ Junior High School } \\
\hline Monitoring & $1^{\text {st }}$ & 09 & & $5.69(2.122)$ & & -.20 & -1.93 \\
\hline Reflective & & & & & & -.13 & -1.19 \\
\hline Monitoring & & & & & & -.06 & -.74 \\
\hline Reflective & $2^{\text {nd }}$ & .47 & & $35.42(3,121)$ & & -.02 & -.26 \\
\hline Self-efficacy & & & .38 & & $86.89(1,121)$ & .66 & 9.32 \\
\hline
\end{tabular}

Note: All F- and Fch-values, $p<.01 ; \mathrm{t}>9.32, p<.01, \mathrm{t}=1.93, p<.05, \mathrm{t}<1.93, p>.05$. 
school teachers and high school teachers, in which school collective-efficacy was the predicted variable and the elements of problem-solving appraisal (entering into first step of the analysis) and self-efficacy (entering into second step of the analysis) were the predictor variables, revealed that: 1) Problem-solving appraisal had low but significant negative effect on collective-efficacy in primary education, $\mathrm{R}^{2}=.10$, and in secondary education, $\mathrm{R}^{2}=.09$, evidencing that the greater perceptions of problem-solving abilities contributes into higher sense of school collective-efficacy, 2) the two sets of predictors, in combination, positively influenced school collective-efficacy, accounting for $55 \%$ and $47 \%$ of the variance in primary and secondary education respectively, 3) self-efficacy had direct effect on collective-efficacy beyond that of problem -solving appraisal in both groups of teachers, $\mathrm{R}^{2} \mathrm{ch}=.45$ and $\left.\mathrm{R}^{2} \mathrm{ch}=.38,4\right)$ self-efficacy, beta $=.66, \mathrm{t}=9.32, p<.01$, and reflective style of problem-solving, beta $=-.20, \mathrm{t}=-1.93, p<.05$, contributed into generation of collective-efficacy in the group of junior high schools teachers, while, in primary school, self-efficacy was the solo formulator of collective-efficacy, beta $=.77, \mathrm{t}=11.22, p<.01$.

These results partially confirmed Hypothesis $4 \mathrm{c}$.

\subsubsection{The Interactive Role of Self-Efficacy, Problem-Solving Appraisal and Collective-Efficacy on Emotions}

The main results from a series of correlation coefficient analyses (Table 3) revealed that the higher the teachers' self-efficacy was, the higher their perceptions of their school efficacy were and the higher their perceptions of the problem-solving ability were, the more intense their positive emotions and the less intense their negative emotions over the school year were. However, the extent of the association of the three sets of the concepts with the emotions varied between and within the two groups of teachers as well as between and within emotions. The pattern of the association of the components of problem-solving appraisal with the emotions, specifically, is rather a complex one. In primary education, as the reflective style, the monitory style and, mainly, the problem-solving confidence increased, the emotional experience at school is better, while impulsive style was only related to the emotions of nervousness and anxiety, and personal control had no association. In secondary education, as the elements of problem-solving increased, so did the intensity of the positive emotions.

To examine the mediate role of teachers' self-efficacy in the interactive impact of problem-solving appraisal and collective efficacy on teachers' experienced emotions at school, a series of hierarchical regression analyses, separately for primary school teachers and junior school teachers (Table 6), were conducted. Each of the emotions was the predicted variable and self-efficacy (entering into third step), components of problem-solving appraisal (entering into second step) and collective-efficacy (entering into first step) were the predictors. Only the variables that were related each other were included in each of the analyses.

The findings revealed that the three concepts, as a group, explained a moderate amount of the variance of the emotions in primary school teachers, 
Table 6. Results from hierarchical regression analyses for the role of teachers' self-efficacy on the impact of problem-solving appraisal on the effect of collective-efficacy on the emotions in association to teaching level (primary/junior high school).

\begin{tabular}{|c|c|c|c|c|c|c|c|c|c|c|c|c|}
\hline \multirow{2}{*}{ Emotions } & \multicolumn{6}{|c|}{ Primary School } & \multicolumn{6}{|c|}{ Junior High School } \\
\hline & & Steps & $\mathrm{R}^{2}$ & $\mathrm{R}^{2} \mathrm{ch}$ & $\mathrm{F}$ & Fch & & Steps & $\mathrm{R}^{2}$ & $\mathrm{R}^{2} \mathrm{ch}$ & $\mathrm{F}$ & Fch \\
\hline \multirow[t]{6}{*}{ Happiness } & Collective-efficacy & $1^{\text {st }}$ & .15 & & 22.72 & & Collective-efficacy & $1^{\text {st }}$ & .27 & & 45.83 & \\
\hline & & & & & & & Collective-efficacy & & & & & \\
\hline & & & & & & & Monitoring & $2^{\text {nd }}$ & .28 & -- & 23.13 & -- \\
\hline & & & & & & & Collective-efficacy & & & & & \\
\hline & Collective-efficacy & & & & & & Monitoring & & & & & \\
\hline & Self-efficacy & $2^{\text {nd }}$ & .23 & .09 & 19.60 & 14.16 & Self-efficacy & $3^{\text {rd }}$ & .36 & .08 & 22.54 & 15.77 \\
\hline \multirow[t]{10}{*}{ Satisfaction } & Collective-efficacy & $1^{\text {st }}$ & .34 & & 65.54 & & Collective-efficacy & $1^{\text {st }}$ & .24 & & 38.53 & \\
\hline & Collective-efficacy & & & & & & & & & & & \\
\hline & Confidence & & & & & & & & & & & \\
\hline & Monitoring & & & & & & & & & & & \\
\hline & Reflective & $2^{\text {nd }}$ & .35 & -- & 17.10 & -- & Collective-efficacy & & & & & \\
\hline & Collective-efficacy & & & & & & & & & & & \\
\hline & Confidence & & & & & & & & & & & \\
\hline & Monitoring & & & & & & & & & & & \\
\hline & Reflective & & & & & & & & & & & \\
\hline & Self-efficacy & $3^{\text {rd }}$ & .39 & .04 & 16.25 & 8.66 & Self-efficacy & $2^{\text {nd }}$ & .32 & .08 & 29.17 & 15.33 \\
\hline \multirow[t]{8}{*}{ Pleasure } & Collective-efficacy & $1^{\text {st }}$ & .30 & & 55.64 & & Collective-efficacy & $1^{\text {st }}$ & .26 & & 43.55 & \\
\hline & Collective-efficacy & & & & & & Collective-efficacy & & & & & \\
\hline & & & & & & & Monitoring & & & & & \\
\hline & Confidence & $2^{\text {nd }}$ & .30 & -- & 28.00 & -- & Reflective & $2^{\text {nd }}$ & .27 & -- & 14.79 & -- \\
\hline & Collective-efficacy & & & & & & Collective-efficacy & & & & & \\
\hline & & & & & & & Monitoring & & & & & \\
\hline & Confidence & & & & & & Reflective & & & & & \\
\hline & Self-efficacy & $3^{\text {rd }}$ & .34 & .04 & 22.25 & 7.78 & Self-efficacy & $3^{\text {rd }}$ & .33 & .06 & 14.49 & 10.22 \\
\hline \multirow[t]{8}{*}{ Pride } & Collective-efficacy & $1^{\text {st }}$ & .19 & & 30.79 & & Collective-efficacy & $1^{\text {st }}$ & .28 & & 46.55 & \\
\hline & Collective-efficacy & & & & & & & & & & & \\
\hline & Confidence & & & & & & Collective-efficacy & & & & & \\
\hline & Reflective & $2^{\text {nd }}$ & .21 & -- & 11.47 & -- & Reflective & $2^{\text {nd }}$ & .28 & -- & 24.20 & -- \\
\hline & Collective-efficacy & & & & & & Collective-efficacy & & & & & \\
\hline & Confidence & & & & & & Reflective & & & & & \\
\hline & Reflective & & & & & & & & & & & \\
\hline & Self-efficacy & $3^{\mathrm{rd}}$ & .35 & .14 & 16.90 & 26.33 & Self-efficacy & $3^{\text {rd }}$ & .36 & .08 & 23.15 & 15.40 \\
\hline \multirow{2}{*}{$\begin{array}{l}\text { Encourage- } \\
\text { ment }\end{array}$} & Collective-efficacy & $1^{\mathrm{st}}$ & .29 & & 53.17 & & Collective-efficacy & $1^{\mathrm{st}}$ & .28 & & 47.50 & \\
\hline & Collective-efficacy & $2^{\text {nd }}$ & .31 & -- & 18.96 & -- & Collective-efficacy & $2^{\text {nd }}$ & .32 & .05 & 28.90 & 7.72 \\
\hline
\end{tabular}




\section{Continued}

\begin{tabular}{|c|c|c|c|c|c|c|c|c|c|c|c|c|}
\hline & Confidence & & & & & & & & & & & \\
\hline & Reflective & & & & & & & & & & & \\
\hline & Collective-efficacy & & & & & & & & & & & \\
\hline & Confidence & & & & & & & & & & & \\
\hline & Reflective & & & & & & & & & & & \\
\hline & Self-efficacy & $3^{\text {rd }}$ & .34 & .03 & 16.36 & 6.21 & Self-efficacy & & & & & \\
\hline Confidence & Collective-efficacy & $1^{\mathrm{st}}$ & .24 & & 41.68 & & & & & & & \\
\hline & Collective-efficacy & & & & & & & & & & & \\
\hline & Reflective & $2^{\text {nd }}$ & .26 & -- & 22.14 & -- & Collective-efficacy & $1^{\mathrm{st}}$ & .17 & & 25.10 & \\
\hline & Collective-efficacy & & & & & & Collective-efficacy & & & & & \\
\hline & Reflective & & & & & & & & & & & \\
\hline & Self-efficacy & $3^{\text {rd }}$ & .31 & .05 & 18.73 & 9.12 & Self-efficacy & $2^{\text {nd }}$ & .20 & .03 & 15.37 & 4.87 \\
\hline Calmness & Collective-efficacy & $1^{\mathrm{st}}$ & .23 & & 38.19 & & Collective-efficacy & $1^{\mathrm{st}}$ & .13 & & 17.57 & \\
\hline & Collective-efficacy & & & & & & Collective-efficacy & & & & & \\
\hline & & & & & & & Monitoring & & & & & \\
\hline & Confidence & $2^{\text {nd }}$ & .26 & .03 & 21.92 & 4.58 & Reflective & $2^{\text {nd }}$ & .14 & -- & 6.72 & -- \\
\hline & Collective-efficacy & & & & & & Collective-efficacy & & & & & \\
\hline & & & & & & & Monitoring & & & & & \\
\hline & Confidence & & & & & & Reflective & & & & & \\
\hline & Self-efficacy & $3^{\text {rd }}$ & .27 & -- & 15.51 & -- & Self-efficacy & $3^{\text {rd }}$ & .21 & .07 & 8.25 & 11.10 \\
\hline Anger & Collective-efficacy & $1^{\text {st }}$ & .26 & & 45.48 & & & $1^{\text {st }}$ & .03 & & 4.20 & \\
\hline & Collective-efficacy & & & & & & & & & & & \\
\hline & Confidence & & & & & & Collective-efficacy & & & & & \\
\hline & Monitoring & & & & & & & & & & & \\
\hline & Reflective & $2^{\text {nd }}$ & .30 & .04 & 13.41 & 3.27 & Monitoring & $2^{\text {nd }}$ & .05 & -- & 3.35 & -- \\
\hline & Collective-efficacy & & & & & & Collective-efficacy & & & & & \\
\hline & Confidence & & & & & & & & & & & \\
\hline & Monitoring & & & & & & & & & & & \\
\hline & Reflective & & & & & & Monitoring & & & & & \\
\hline & Self-efficacy & $3^{\mathrm{rd}}$ & .39 & .09 & 15.67 & 17.65 & Self-efficacy & $3^{\mathrm{rd}}$ & .12 & .07 & 5.56 & 9.53 \\
\hline Flow & Collective-efficacy & $1^{\text {st }}$ & .21 & & 33.55 & & Collective-efficacy & $1^{\mathrm{st}}$ & .15 & & 21.92 & \\
\hline & Collective-efficacy & & & & & & Collective-efficacy & & & & & \\
\hline & & & & & & & Monitoring & & & & & \\
\hline & Monitoring & $2^{\text {nd }}$ & .22 & -- & 17.74 & -- & Reflective & $2^{\text {nd }}$ & .18 & -- & 8.87 & -- \\
\hline & Collective-efficacy & & & & & & & & & & & \\
\hline & & & & & & & Collective-efficacy & & & & & \\
\hline & Monitoring & & & & & & Monitoring & & & & & \\
\hline & Self-efficacy & $3^{\text {rd }}$ & .25 & .03 & 14.27 & 5.94 & Self-efficacy & $3^{\text {rd }}$ & .20 & & 7.38 & \\
\hline
\end{tabular}




\section{Continued}

\begin{tabular}{|c|c|c|c|c|c|c|c|c|c|c|c|c|}
\hline \multirow[t]{8}{*}{ Cheerfulness } & Collective-efficacy & $1^{\mathrm{st}}$ & .27 & & 48.14 & & Collective-efficacy & $1^{\text {st }}$ & .24 & & 39.08 & \\
\hline & Collective-efficacy & & & & & & Collective-efficacy & & & & & \\
\hline & Confidence & & & & & & Monitoring & & & & & \\
\hline & Reflective & $2^{\text {nd }}$ & .28 & -- & 16.50 & -- & Reflective & $2^{\text {nd }}$ & .25 & -- & 13.69 & -- \\
\hline & Collective-efficacy & & & & & & Collective-efficacy & & & & & \\
\hline & Confidence & & & & & & Monitoring & & & & & \\
\hline & Reflective & & & & & & Reflective & & & & & \\
\hline & Self-efficacy & $3^{\text {rd }}$ & .36 & .08 & 17.89 & 16.14 & Self-efficacy & $3^{\text {rd }}$ & .32 & .07 & 14.58 & 13.13 \\
\hline \multirow[t]{8}{*}{ Excitement } & Collective-efficacy & $1^{\mathrm{st}}$ & .20 & & 32.22 & & Collective-efficacy & $1^{\text {st }}$ & .10 & & 14.05 & \\
\hline & Collective-efficacy & & & & & & Collective-efficacy & & & & & \\
\hline & Monitoring & & & & & & Monitoring & & & & & \\
\hline & 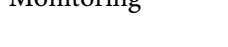 & $2^{\text {nd }}$ & .22 & -- & 17.78 & -- & Reflective & $2^{\text {nd }}$ & .12 & -- & 5.63 & -- \\
\hline & Collective-efficacy & & & & & & Collective-efficacy & & & & & \\
\hline & & & & & & & Monitoring & & & & & \\
\hline & Monitoring & & & & & & Reflective & & & & & \\
\hline & Self-efficacy & $3^{\text {rd }}$ & .26 & .04 & 14.73 & 6.98 & Self-efficacy & $3^{\text {rd }}$ & .21 & .09 & 8.27 & 14.32 \\
\hline \multirow[t]{6}{*}{ Irritation } & Collective-efficacy & $1^{\mathrm{st}}$ & .28 & & 50.79 & & Collective-efficacy & $1^{\text {st }}$ & .20 & & 30.60 & \\
\hline & Collective-efficacy & & & & & & Collective-efficacy & & & & & \\
\hline & Confidence & $2^{\text {nd }}$ & .29 & -- & 25.71 & -- & Reflective & $2^{\text {nd }}$ & .20 & -- & 15.70 & -- \\
\hline & Collective-efficacy & & & & & & Collective-efficacy & & & & & \\
\hline & Confidence & & & & & & Reflective & & & & & \\
\hline & Self-efficacy & $3^{\text {rd }}$ & .31 & .02 & 19.22 & 4.74 & Self-efficacy & $3^{\text {rd }}$ & .20 & -- & 10.60 & -- \\
\hline \multirow[t]{6}{*}{ Hope } & Collective-efficacy & $1^{\mathrm{st}}$ & .22 & & 36.05 & & Collective-efficacy & $1^{\text {st }}$ & .20 & & 30.42 & \\
\hline & Collective-efficacy & & & & & & Collective-efficacy & & & & & \\
\hline & Confidence & $2^{\text {nd }}$ & .23 & -- & 19.25 & -- & & & & & & \\
\hline & Collective-efficacy & & & & & & & & & & & \\
\hline & Confidence & & & & & & & & & & & \\
\hline & Self-efficacy & $3^{\text {rd }}$ & .26 & .03 & 14.56 & 4.20 & Self-efficacy & $2^{\text {nd }}$ & .27 & .07 & 22.15 & 11.35 \\
\hline \multirow[t]{8}{*}{ Competence } & Collective-efficacy & $1^{\text {st }}$ & .11 & & 15.18 & & Collective-efficacy & $1^{\text {st }}$ & .09 & & 11.53 & \\
\hline & Collective-efficacy & & & & & & Collective-efficacy & & & & & \\
\hline & Confidence & & & & & & & & & & & \\
\hline & Monitoring & $2^{\text {nd }}$ & .12 & -- & 5.91 & -- & Reflective & $2^{\text {nd }}$ & .10 & -- & 7.32 & -- \\
\hline & Collective-efficacy & & & & & & Collective-efficacy & & & & & \\
\hline & Confidence & & & & & & Reflective & & & & & \\
\hline & Monitoring & & & & & & & & & & & \\
\hline & Self-efficacy & $3^{\text {rd }}$ & .26 & .14 & 11.34 & 24.34 & Self-efficacy & $3^{\text {rd }}$ & .20 & .10 & 10.35 & 14.76 \\
\hline
\end{tabular}




\section{Continued}

\begin{tabular}{|c|c|c|c|c|c|c|c|c|c|c|c|c|}
\hline \multirow[t]{8}{*}{ Nervousness } & Collective-efficacy & $1^{\mathrm{st}}$ & .27 & & 47.60 & & Collective-efficacy & $1^{\mathrm{st}}$ & .13 & & 17.75 & \\
\hline & Collective-efficacy & & & & & & & & & & & \\
\hline & Confidence & & & & & & Collective-efficacy & & & & & \\
\hline & Monitoring & $2^{\text {nd }}$ & .32 & .05 & 19.81 & 4.59 & Self-efficacy & $2^{\text {nd }}$ & .22 & .09 & 17.08 & 14.50 \\
\hline & Collective-efficacy & & & & & & & & & & & \\
\hline & Confidence & & & & & & & & & & & \\
\hline & Monitoring & & & & & & & & & & & \\
\hline & Self-efficacy & $3^{\text {rd }}$ & .44 & .12 & 25.08 & 28.16 & & & & & & \\
\hline \multirow[t]{6}{*}{ Anxiety } & Collective-efficacy & $1^{\mathrm{st}}$ & .17 & & 26.12 & & Collective-efficacy & $1^{\mathrm{st}}$ & .11 & & 15.65 & \\
\hline & Collective-efficacy & & & & & & Collective-efficacy & & & & & \\
\hline & Confidence & $2^{\text {nd }}$ & .22 & .05 & 18.40 & 9.05 & Self-efficacy & $2^{\text {nd }}$ & .36 & .25 & 34.94 & 48.20 \\
\hline & Collective-efficacy & & & & & & & & & & & \\
\hline & Confidence & & & & & & & & & & & \\
\hline & Self-efficacy & $3^{\text {rd }}$ & .28 & .06 & 16.83 & 10.86 & & & & & & \\
\hline \multirow[t]{8}{*}{ Enthusiasm } & Collective-efficacy & $1^{\mathrm{st}}$ & .19 & & 30.85 & & Collective-efficacy & $1^{\text {st }}$ & .27 & & 54.90 & \\
\hline & Collective-efficacy & & & & & & & & & & & \\
\hline & Confidence & & & & & & Collective-efficacy & & & & & \\
\hline & Reflective & $2^{\text {nd }}$ & .22 & .03 & 12.31 & 2.65 & Self-efficacy & $2^{\text {nd }}$ & .34 & .07 & 31.85 & 13.30 \\
\hline & Collective-efficacy & & & & & & & & & & & \\
\hline & Confidence & & & & & & & & & & & \\
\hline & Reflective & & & & & & & & & & & \\
\hline & Self-efficacy & $3^{\text {rd }}$ & .28 & .06 & 12.74 & 11.07 & & & & & & \\
\hline \multirow[t]{8}{*}{ Boredom } & Collective-efficacy & $1^{\mathrm{st}}$ & .16 & & 24.41 & & Collective-efficacy & $1^{\text {st }}$ & .11 & & 15.68 & \\
\hline & Collective-efficacy & & & & & & & & & & & \\
\hline & Monitoring & & & & & & Collective-efficacy & & & & & \\
\hline & Reflective & $2^{\text {nd }}$ & .17 & -- & 8.81 & -- & Self-efficacy & $2^{\text {nd }}$ & .27 & .16 & 22.36 & 25.90 \\
\hline & Collective-efficacy & & & & & & & & & & & \\
\hline & Monitoring & & & & & & & & & & & \\
\hline & Reflective & & & & & & & & & & & \\
\hline & Self-efficacy & $3^{\text {rd }}$ & .21 & .04 & 8.67 & 6.99 & & & & & & \\
\hline
\end{tabular}

Note: $\mathrm{F} \leq 4.20, p<.05 ; \mathrm{F}>4.20, p<.01 ; \mathrm{Fch} \leq 4.87, p<.05 ; \mathrm{F}>4.87, p<.01 ;--: \mathrm{F}$ - and Fch-values, $p>.05$.

$\mathrm{R}^{2}$ ranged from .21 (boredom) to .44 (nervousness), and in junior high school teachers, $\mathrm{R}^{2}$ ranged from.12 (anger) to .36 (happiness, pride and low anxiety), showing their determinative role in teachers' emotions, particularly in the self-, task-, goal- and context-related emotions.

It was also found that, while the efficacy beliefs and problem-solving appraisal accounted in the variance in the emotional experience, their relative power in in- 
fluencing emotions differed across the emotions and within each emotion. It seems that self-efficacy mainly influenced the self-, goal- and task-related emotions, collective-efficacy most predicted task- and activity-dependent emotions, while problem-solving appraisal was mainly associated with the goal-, othersand task-related emotions.

The findings regarding self-efficacy revealed that it had positive indirect, through the interaction of problem-solving and collective-efficacy, and direct, $\mathrm{R}^{2}$ ch ranged from .02 (irritation) to .14 (pride and competence) in primary school teachers group, and from .03 (confidence) to .26 (anxiety) in secondary school teachers, effects on the emotions. Also, self-efficacy, compared to both collective-efficacy and problem-solving appraisal, proved the most powerful formulator of most of the emotions in both groups of teachers.

Specifically, in the group of primary school teachers, self-efficacy was the solo and positive contributor into the generation of the emotions of competency (be$\mathrm{ta}=.61, \mathrm{t}=4.93, p<.01$ ), pride (beta $=.59, \mathrm{t}=5.13, p<.01$ ), low nervousness (beta $=.57, \mathrm{t}=5.31, p<.01$ ), low anger (beta $=.48, \mathrm{t}=4.20, p<.01$ ), cheerfulness (beta $=.46, \mathrm{t}=4.02, p<.01$ ), happiness (beta $=.43, \mathrm{t}=3.76, p<.01)$, low anxiety (beta $=.40, \mathrm{t}=3.30, p<.01)$, low boredom (beta $=.33, \mathrm{t}=2.64, p<.01$ ) and flow (beta $=.32, \mathrm{t}=2.64, p<.01$ ). In addition, self-efficacy was a positive predictor but to less extent, relative to collective-efficacy, of the emotions of enthusiasm (beta $=.40, \mathrm{t}=3.30, p<.01$ ), confidence (beta $=.34, \mathrm{t}=3.05, p<.01$ ), pleasure (beta $=.31, \mathrm{t}=2.79, p<.01)$, satisfaction (beta $=.31, \mathrm{t}=2.95, p<.01)$, encouragement (beta $=.29, \mathrm{t}=2.50, p<.01)$ and hope (beta $=.25, \mathrm{t}=2.05, p$ $<.05)$.

Similarly, in the group of junior high school teachers, self-efficacy, compared to problem-solving appraisal and collective-efficacy, was a better predictor of the emotions of happiness (beta $=.40, \mathrm{t}=3.97, p<.01)$, satisfaction (beta $=.40, \mathrm{t}=$ $3.92, p<.01$ ), pride (beta $=.40, \mathrm{t}=3.93, p<.01)$, cheerfulness $($ beta $=.38, \mathrm{t}=$ $3.62, p<.01$ ), hope (beta $=.36, \mathrm{t}=3.37, p<.01$ ), enthusiasm (beta $=.36, \mathrm{t}=$ $3.64, p<.01$ ), while it was the solo formulating factor of the emotions of exciting (beta $=.43, \mathrm{t}=3.78, p<.01$ ), competence (beta $=.43, \mathrm{t}=3.84, p<.01$ ), calmness (beta $=.38, \mathrm{t}=3.33, p<.01$ ), no anger (beta $=.36, \mathrm{t}=3.09, p<.01$ ), no nervousness (beta $=.42, \mathrm{t}=3.80, p<.01)$, no anxiety (beta $=.68, \mathrm{t}=6.94, p<.01$ ) and no boredom (beta $=.54, \mathrm{t}=5.09, p<.01$ ). It also accounted in the variance of the emotions of encouragement (beta $=.28, \mathrm{t}=2.80, p<.01$ ) and confidence (beta $=.23, \mathrm{t}=2.20, p<.05)$.

The results with respect to collective-efficacy support that, in the group of primary school teachers, collective-efficacy, compared to problem-solving appraisal and self-efficacy, was a more powerful formulator of the emotions of low irritation (beta $=.34, \mathrm{t}=3.12, p<.01$ ), satisfaction (beta $=.33, \mathrm{t}=3.16, p<.01$ ), pleasure (beta $=.32, \mathrm{t}=2.99, p<.01)$, encouragement (beta $=.32, \mathrm{t}=2.96, p$ $<.01$ ), hope (beta $=.27, \mathrm{t}=2.39, p<.05)$ and calmness (beta $=.31, \mathrm{t}=2.74, p$ $<.01)$ in which was the solo contributor. It also contributed into the emotions of confidence (beta $=.23, \mathrm{t}=2.11, p<.05)$ and flow (beta $=.23, \mathrm{t}=2.0, p<.05)$. 
In the group of junior high school teachers, perceived school collective-efficacy, relative to problem-solving appraisal and self-efficacy, was a more powerful formulator of the emotions of encouragement (beta $=.34, \mathrm{t}=3.30, p<.01$ ) and confidence (beta $=.25, \mathrm{t}=2.23, p<.05$ ), whereas was the solo influential factor of the emotions of irritation (beta $=.38, \mathrm{t}=3.40, p<.01$ ) and flow (beta $=.22, \mathrm{t}$ $=1.97, p<.05)$. In addition, collective-efficacy contributed in the emotions of pleasure (beta $=.28, \mathrm{t}=2.70, p<.01), \mathrm{e})$, enthusiasm (beta $=.27, \mathrm{t}=2.73, p$ $<.01$ ), happiness (beta $=.25, \mathrm{t}=2.47, p<.05)$, pride (beta $=.24, \mathrm{t}=2.47, p$ $<.05$ ), satisfaction (beta $=.22, \mathrm{t}=2.10, p<.05$ ), cheerfulness (beta $=.22, \mathrm{t}=$ $2.10, p<.05)$ and hope (beta $=.20, \mathrm{t}=1.95, p<.05)$.

Problem-solving appraisal proved a positive but a weak formulator of the emotions, compared to efficacy beliefs, because it only enhanced the impact of primary school teachers' collective-efficacy beliefs on their emotions of calmness, $\mathrm{R}^{2} \mathrm{ch}=.03$, enthusiasm, $\mathrm{R}^{2} \mathrm{ch}=.03$, anger, $\mathrm{R}^{2} \mathrm{ch}=.04$, nervousness, $\mathrm{R}^{2} \mathrm{ch}$ $=.05$, and anxiety, $\mathrm{R}^{2} \mathrm{ch}=.05$. However, only confidence in problem solving had significant unique contribution in the generation of the emotions of calmness, $\mathrm{b}$ $=-.17, \mathrm{t}=2.14, p<.05$, low anger, $\mathrm{b}=-.21, \mathrm{t}=2.35, p<.05$, low nervousness, $\mathrm{b}$ $=-.25, \mathrm{t}=2.95, p<.01$, and low anxiety, $\mathrm{b}=-.24, \mathrm{t}=3.10, p<.01,=.05$, while reflective style contributed in the emotion of enthusiasm, $\mathrm{b}=-.18, \mathrm{t}=1.98, p$ $<.05$. Reflective style, additionally, had direct effect on the emotion of enthusiasm beyond that of both self-efficacy and collective efficacy, $\mathrm{b}=-.17, \mathrm{t}=1.95$, $p<.05$. In the group of junior high school teachers, problem-solving appraisal had only indirect effect on the emotions via efficacy beliefs.

These results partially confirmed Hypotheses $5 \mathrm{a}, 5 \mathrm{~b}$ and $5 \mathrm{c}$.

\section{Discussion}

This research stresses teachers' emotions that have been very limitedly investigated. This study also provides insight into how teachers' self-efficacy beliefs, collective-efficacy beliefs and problem-solving appraisal may be linked, how these concepts interactively influence teacher emotions experienced at school, and how these constructs and their inter-effects may vary by the educational level in which the teachers teach. The results in the main supported the present hypotheses and previous researches, while unexpected findings stimulate further investigation on the topic.

\subsection{Efficacy Beliefs}

The findings from the present study, in consistency with past research evidence (Caprara, Barbarenelli, Borgogni, Petitta et al., 2003; Dembo \& Gibson, 1985; Klassen et al., 2010; Lee, Cawthon, \& Dawson, 2013; Rimm-Kaufman \& Sawyer, 2004; Stephanou et al., 2013; Wolters \& Daugherty, 2007), revealed that teachers had from moderate to high sense of self-efficacy and school collective-efficacy.

Based on Bandura's (1997) theoretical conception regarding the sources of self-efficacy, the participants' great range of teaching experience may be an ex- 
planation for this specific self-efficacy result. Research has shown that teachers with long professional experience have been exposed to difficulties and have overcome challenging situations that allow them to develop robust skills and be confident (see Klassen \& Chiu, 2010; Ross et al., 1996; Tschannen-Moran \& Hoy, 2007; Wolters \& Daugherty, 2007). Furthermore, mastery experiences, which are those that build upon the knowledge base, consist a crucial source of self-efficacy of career teachers, while vicarious experiences and contextual factors affect more self-efficacy beliefs in novice teachers (see Klassen et al., 2010; Tschannen-Moran \& Hoy, 2007). In this study, the middle and long career teachers, perhaps, had overcome effectively the obstacles and difficulties that allowed them to build a high sense of self-efficacy, while the novice teachers had, probably, formulated satisfactory sense of self-efficacy via their interactions with the experienced colleagues.

Teachers also believed that they can work with others, such as colleagues, parents and administrators, effectively to accomplish their shared goals and their school's mission (see Caprara, Barbarenelli, Borgogni, Petitta et al., 2003; Mawhinney et al., 2005; Ross \& Gray, 2006; Stephanou et al., 2013; Tschannen-Moran \& Barr, 2004). Teachers' professional experience, as above mentioned, might be an influential factor to this finding, since mastery experiences (e.g., Goddard, 2001; Hass, 2005) and social persuasion (e.g., Goddard et al., 2004) that involves direct engagement and support from leaders and other experienced colleagues have been found to influence positively collective-efficacy beliefs.

The high importance of the professional role for the participants' self-identity might be an additive explanatory factor for the efficacy beliefs result, since under high ego involvement conditions individuals try to be socially acceptable. In the present study, the teachers, probably, are socially acceptable and enhance their ego by contributing into effective school which pre-requires team effort (see Lindsley, Brass, \& Thomas, 1995). Also, the involved state/public schools in this study might contribute into understanding the reported level of self- and collective-efficacy. Specifically, a successful public school copes with the various challenges and outside pressure, and, doing so, strengthens the teachers' beliefs in their abilities that are linked positively to their school's readiness to be a professional learning community (see Bandura, 1997; Hass, 2005; Mawhinney et al., 2005).

The findings from this research, in contrast to our expectations, previous studies (e.g., Greenwood et al., 1990; Guskey, 1987; Klassen \& Chiu, 2010; Midgley, Feldlaufer, \& Eccles, 1988; Tschannen-Moran \& Hoy, 2007; Wolters \& Daugherty, 2007) and Bandura's (1993) suggestion that as the complexity of the educational demands increases, through educational level, the teachers' efficacy decreases, reported no differences between the primary and secondary school teachers' self-efficacy. These results, in part, may be explained by the fact that the teachers from both teaching levels had similar professional experience and profile. However, research needs to specify such finding. 
On the other hand, although the teachers from both teaching levels reported from moderate to high collective-efficacy beliefs, primary school teachers consider their school more effective than high school teachers, consistent with previous research (Mawhinney et al., 2005). This is in line with the notation that academic levels represent distinct contexts with unique and specific characteristics regarding underlying organization and climate, the training and background of the educational staff, and the students they serve. For example, primary schools are smaller in size and facilitate direct and frequent contact with students, colleagues and parents, and are open to the local community, promoting, thus, a sense of school collective effectiveness (Hoy \& Miskel, 2008; Mawhinney et al., 2005; Midgley, Feldlaufer, \& Eccles, 1989; Ross, 1994).

The results from the current study reinforce previous findings (e.g., Goddard et al., 2004), showing that teacher- and collective-efficacy covary positively. Accurately, in both teaching levels, teachers' self-efficacy was a formative factor of their collective-efficacy beliefs, confirming previous studies (e.g., Caprara, Barbarenelli, Borgogni, Petitta et al., 2003; Demir, 2008; Stephanou et al., 2013). These results agree with Bandura's (2001) contention that collective efficacy beliefs are not independent of the perceptions and actions of those who constitute the social system and highlight the importance of individual factors in enhancing team effectiveness and team performance (Bandura, 2001; Baker, 2001; Katz-Navon \& Erez, 2005). This was more evident in primary school than in junior high school, suggesting that the link of teacher self- and collective-efficacy is socially and contextually constructed.

Overall, teachers' efficacy beliefs reflect a supportive learning environment for the students, which in turn may contribute to further increase in teachers' efficacy, as past research indicates (see Goddard et al., 2004; Tschannen-Moran \& Hoy, 2007). On the other hand, the results underline a need for further research on the antecedents of teachers' efficacy beliefs.

\subsection{Problem-Solving Appraisal}

The findings regarding problem-solving appraisal are consistent with previous research findings, supporting that teachers are trying to find solutions to their problems through their assertive resolve (see Betoret, 2006; Betoret \& Artiga, 2010). Specifically, teachers, in both teaching levels, felt from moderately to highly effective in solving their daily problems. They reported a tendency to approach their problems, notably through monitoring style, by trying to identify, collect and explore, as much as possible, further information. The participants also referred to reflective problem-solving style which is linked to systematic use of rational, open and effective skills (see D'Zurilla, Nezu, \& Maydeu-Olivares, 2004). Similarly, they declared self-confidence in problem solving which, as Deniz (2004) supports, is associated with high self-efficacy, more cautious behavior in taking a decision, less panicked behavior and less evasive manner. Also, the teachers indicated, to less extent, a moderate level of control in their emotions 
and behavior in problem-solving process, underling its distinct role in solving the problems.

The reported confidence and rational thinking in problem-solving did not differ between the teaching levels. This specific finding might relate to the fact that both groups of teachers had the same level of education, supporting previous research that individuals with higher educational levels have more positive problem-solving appraisal (see Felton, Parsons, \& Bartoces, 1997). Also, as the two groups of teachers had the same age, they did not differ in problem-solving appraisal (see Heppner et al., 2004). In addition, the estimates for problem solving consists a general personality trait that is not determined by specific situations (Heppner, 2008). According to Heppner (2008), the general cultural context affects all aspects of resolving and addressing the problem, namely how perceived problem-solving strategies available and acceptable solutions (see Cheung, 2000; Heppner, 2008; Wong \& Wong, 2006). The participant teachers came from the same socio-cultural context that probably has become a structuring agent of the general belief in solving their problems. On the other hand, the primary school teachers were reported as more careful and persistent in problem-solving efforts than secondary school teachers, while the latter displayed significantly higher level of control on their emotions and behavior when dealing with problem solution than primary school teachers. This might be partly explained by the fact that primary school consists conducive framework consecutive social interactions that facilitate closer contact between teachers and students' families, and the opening to the local community (Hoy \& Miskel, 2008; Midgley, Middleton, Gheen, \& Kummar, 2012). Under such conditions, teachers feel more pressured to resolve the various problems they face but also quite cautious so as not to jeopardize their professional identity.

\subsection{Inter-Effects of Efficacy Beliefs and Problem-Solving Appraisal}

Teachers' self-efficacy was a key factor in shaping their perceptions about their ability in solving the daily problems, supporting the view that self-efficacy enhances the individual's beliefs about his/her capabilities to deal effectively with difficult situations (Bandura, 1982, 1997; Heppner, 2008).

Self-efficacy influenced predominately confidence than the rest of the components of problem solving appraisal, supporting its positive role in considering the problem as a treatable condition that is a motivating factor of resolving the problem (Carver \& Connor-Smith, 2010; Carver, Scheier, \& Weintraub; 1989; D’Zurilla \& Nezu, 2010; Heppner et al., 2001; Heppner \& Lee, 2002; Karademas \& Kalantzi-Azizi, 2004; Stetz et al., 2006; Weiten, Dunn, \& Hammer, 2011). This result supports other research findings showing that teachers with a high sense of self-efficacy are characterized by confidence and adaptability to any failures with the students, insist on difficulties, and encounter in relation to classroom management and student discipline problems (Caprara, Barbarenelli, Borgogni, Petitta et al., 2003; Dembo \& Gibson, 1985; Rimm-Kaufman \& Sawyer, 2004; 
Woolfolk, Rosoff, \& Hoy, 1990).

Also, as expected (see Bandura, 2006; Betoret, 2006; Betoret \& Artiga, 2010), a high sense of self-efficacy was associated with rational thinking and search of diverse and more flexible strategies to solve the problem. This specific finding might hind that teachers with these characteristics actively involved in teaching and learning process, resulting in students' progress (see Evers et al., 2002; Stephanou \& Tsapakidou, 2007; Wolters \& Daugherty, 2007).

The findings from the present research indicate that as the problem-solving appraisal increases, the collective-efficacy increases, suggesting that effective problem solvers teachers, in contrast to ineffective problem solves teachers, are more likely to engage in a school problem, develop good relationships with colleagues, participate in social activities, and ask for help and offer support (Battistich et al., 1989; Betoret, 2006; Erozkan, 2013; Heppner \& Lee, 2002; Heppner et al., 2002). Further, these constructs have been found to contribute into high sense of collective efficacy (Demir, 2008; Mawhinney et al., 2005; Ross \& Gray, 2006). However, except for reflective style, none of the components of problem-solving appraisal had effect on collective-efficacy beyond that of self-efficacy. This specific result indicates the important role of self-efficacy in cognitive processes and in collective-efficacy (Bandura, 1986, 2001; Mawhinney, et al., 2005; Tschannen-Moran \& Barr, 2004).

Research needs to further examine the association of self-efficacy with collective efficacy and the moderator factors, such as problem-solving appraisal which seems to affect to some extent.

\subsection{Emotions}

Teachers, in both teaching levels, experienced a variety of different emotions in school. More precisely, they experienced positive emotions of moderate to high intensity, and moderate to low intense negative emotions, reflecting the wide variability of the sources of the emotions and the high importance of the teachers' professional role in their self-identity (Becker et al., 2014; Erb, 2002; Frenzel, 2014; Hargreaves, 2000; Lasky, 2000; Pekrun, 2006; Stephanou et al., 2013; Stephanou \& Mastora, 2013; Sutton \& Wheatley, 2003; Weiner, 2005; Zembylas, 2003).

As supported by previous studies (e.g., Acee, Kim, Kim et al., 2010; Becker et al., 2014; Demetriou, Wilson, \& Winterbottom, 2009; Pekrun et al., 2010; Stephanou et al., 2013), and by the contention that emotions cannot be understood without understanding the social context in which they emerge (Boiger \& Mesquita 2012; Efklides \& Volet, 2005; Frijda, 2009) and the individual's appraisal of his/her capabilities in achievement a certain goal in a concrete condition (Barrett, Lindquist, Bliss-Moreau, Duncan, Gendron, Mize, \& Brennan, 2007; Izard, 2007; Sutton \& Wheatley, 2003), teachers experienced emotions that are related to context, self and task, such as competence, flow and pride. Also, excitement, which is related to unpredictability of teaching (Sutton \& Wheatley, 2003), was 
one of the most salient emotions among teachers. In addition, pleasure and satisfaction were prevalent positive emotions of teachers that, probably, came from the perceived progress in children (see Shapiro, 2010; Sutton \& Wheatley, 2003) and the anticipatory personal effort to achieve their professional role (Frenzel et al., 2009b).

On the other hand, teachers reported negative emotions of moderate intensity. Specifically, they felt discouragement which, perhaps, resulted from anticipation of upcoming unpredictable or undesirable future event, since it is impossible to accurately predict the variations of school or teaching related factors (see Pekrun, 2006; Pekrun, Maier, \& Elliot, 2009). Furthermore, it seems that the emotion of discouragement was not based on perceived personal inability to fit the professional role, since self-efficacy was not low. Teachers, additionally, experienced the self- and task-related emotion of anxiety, particularly in primary school, and the other-related emotions of irritation and nervousness, mainly in secondary school, underlining the distinct role of significant others, such as school administration, students and colleagues in their well-being (see Buss \& Hughes, 2007; Frenzel et al., 2009a, 2009b; Jennings \& Greenberg, 2009; Lambert et al., 2009; McCormick \& Barnett, 2011; Parrott, 2003; Schutz, Hong, Cross, \& Osbon, 2006; Summers \& Davis, 2006; Sutton \& Wheatley 2003; Yoon, 2002). Irritation and nervousness are usually rising when goal attainment is obstructed. Students' indifference and misbehavior, lack of support by the school or colleagues are sources of such emotions (Becker et al., 2014; Chang, 2009; Hagenauer et al., 2015; Schutz \& Zembylas, 2009; Shapiro, 2010).

Lack of teachers' intense negative emotions rewards prior studies that have shown teachers' positive emotional experiences about their school (e.g., Stephanou et al., 2013), relationships with students (Stephanou \& Mastora, 2013) and classroom teaching (e.g., Hargreaves, 2005; Keller, Goetz, Becker, Morger, \& Hensley, 2014). However, negative emotions cannot be excluded in all situations. For example, previous researches (e.g., Sutton, Mudrey-Camino, \& Knight, 2009) have indicated that many teachers deliberately attempt to intensify positive emotions and reduce negative emotions trying to achieve the most effective teaching. In addition, based on Fried et al.'s (2015) model which incorporates social and political dimensions in teacher emotions, teachers might feel well because they just have a job with a relevant good income, taking into consideration the current hard socio-economical conditions in Greece.

In contrast to previous research evidence that primary school teachers feel more intense positive emotions, while the junior school teachers feel moderate emotions (Hargreaves, 2000, 2001), only five significant differences between primary and secondary teachers' emotions of encouragement, confidence, hope, irritation and anxiety were found. The primary school teachers felt more anxiety than the secondary school teachers, while the latter, compared to the former, experienced more intensely the rest of the emotions.

A possible explanation for the lower intensity of the future-related emotions 
in secondary school teachers may emanate from teachers' isolation with little or no immediate interactions with colleagues, anticipatory low progress in their students and estimative high vulnerability of their school, constructs that are related to lower level of collective-efficacy (see also Frenzel \& Götz, 2007; Frenzel et al., 2009b; Hargreaves, 2001; Midgley et al., 2012; Shapiro, 2010; Stephanou et al., 2013; Zembylas, 2002). It is mentioned that teachers' negative future-related emotions influence low performance expectations that lead to maladaptive future teaching performance and student learning (Becker et al., 2014; Brackett, Floman, Ashton-James, Cherkasskiy, \& Salovey, 2013; Saunders, 2013; Stephanou, 2011). Also, perhaps, the secondary school teachers perceive that their students are undisciplined, and, probably, they attribute the various behavioral or teaching problems to others, such as their students, administrators and colleagues, resulting in irritation and nervousness (see Becker et al., 2015; Chang \& Davis, 2009; Sutton, 2007; Weiner, 2001, 2005).

On the other hand, despite the similar levels of self-efficacy, the higher levels of anxiety in primary school teachers may reflect their agony to satisfy significant others' needs and demands (see Chang, 2009; Darby, 2008). For example, although a close parent-teacher relation is a source of positive emotions, its absence protects the teachers from parents' negative comments and disputes their skills, causing negative emotions (Erb, 2002; Hargreaves, 2001; Kelchtermans, 2005).

It is notably, teachers' excessive anxiety has negatively effects on their well-being and professional performance, and on their students' progress (Becker et al., 2015; Kyriacou, 2001; Lazarus, 2006), while a moderate level of anxiety activates the teachers to redouble their efforts to achieve their professional goals (see Pekrun et al., 2007).

Overall, the pattern of teachers' emotions indicates the high complexity in examining teacher emotions in terms of emotional experience, awareness and report of emotion, sources and dimensions.

\subsection{The Role of Self-Efficacy in the Effect of Collective-Efficacy and Problem-Solving Appraisal on the Emotions}

Efficacy beliefs and problem-solving appraisal, together, were predictors of most the emotions, particularly the related to self and task (pride, satisfaction, low anxiety), to context, activity and goals (pleasure, flow, anxiety, encouragement, enthusiasm), and to others (anger), confirming previous researches supporting that perceptions of self, task, context and relationships with others, uniquely and in combination, are salient antecedents of the emotional experience in school (see Boekaerts \& Corno, 2005; Becker et al., 2014; Frenzel et al., 2009a, 2009b; Pekrun et al., 2010; Saric, 2015; Schutz \& Lenehart, 2002; Stephanou et al., 2013; Weiner, 2001). However, the predictive power of the three constructs, as a group, in teachers' emotions differed between the two teaching levels in favoring primary school level, declaring the higher complexity of the structure of second- 
ary school than primary school, and the respective variety of the sources of the emotions. Also, in primary teaching level, the three concepts, in combination, predominately influenced the generation of the outcome (happiness, satisfaction), task (flow), others (low anger, low nervousness) and future behaviour (confidence, hope) related emotions, underling their significant role in teachers' future behaviour, motivation, well-being and professional development (see Bandura, 2006; Reyna \& Weiner, 2001; Skaalvik \& Skaalvik, 2007; Sutton \& Mudrey-Camino, 2003; Tschannen-Moran \& Woolfolk Hoy, 2001). In secondary teaching level, the interactive influential role of efficacy beliefs and problem-solving appraisal was more salient in outcome (happiness, satisfaction, cheerfulness), self- (pride), task- and goal- (anxiety), future activity and behavior- (confidence, encouragement) related emotions. It seems that the secondary school teachers rather than the primary school teachers might have appraised the status of self- and context-factors in pursuing their goals that include being good in teaching and fitting the mission of their school (see Stephanou et al., 2013).

The higher the efficacy beliefs were, and the more positive the problem-solving appraisal was, more intense the positive emotions and less intense the negative emotions were. However, as expected, self-efficacy, compared to both collective-efficacy and problem-solving appraisal, proved the most powerful formulator of the emotions, with the exception being in the emotions of irritation, satisfaction, pleasure, hope and calmness in primary school teaching, and in the emotions of encouragement, confidence, irritation and flow in high school teaching, that were best predicted by collective-efficacy. Furthermore, the effects of teachers' collective-efficacy beliefs and problem-solving appraisal on their emotions experienced at school were partially mediated by self-efficacy.

Accordantly to the above findings, collective-efficacy was a powerful formulator of the context- and general-related emotions, underling the contribution of the school-related factors, notably the collective effort and cooperation with parents, colleagues and administrators, in developing a high sense of teachers' collective-efficacy which then contributes to their prosperity and positive emotions (see Caprara et al., 2003; Klassen et al., 2010; Mawhinney et al., 2005; Ross \& Gray, 2006). In a similar way, collective-efficacy positively influenced the competitive dependent-emotions, reflecting the teachers' perceptions of their school as capable to control effectively the various difficulties and to satisfy its mission as well as it was a determinant formulator of expectancy-related emotions, rewarding the future-oriented nature of efficacy belies (Bandura, 1997, 2006; Bong \& Skaalvik, 2003; Tschannen-Moran \& Johnson, 2011).

Teachers' sense of self-efficacy was a salient source of pride they experience in school, declaring the high significance of the professional role in their self-identity, since under high ego-involvement conditions individuals emphasize themselves (see Lazarus, 1991; Pekrun, 2006; Scherer, 2001; Stephanou et al., 2013; Weiner, 2005). Moreover, high efficacious individuals have a strong com- 
mitment to their goals, put a lot of effort to achieve them and attribute the fulling of the goals to personal effort, resulting in the emotion of pride. On the other hand, pride might play an important role in teachers' motivation and future behavior (e.g., Eid \& Diener 2004; Grant \& Higgins 2003) which, in turn, enhances self-efficacy, leading to a positive circle.

As Bandura (1997) contends, self-efficacy perceptions regulate emotional state. For example, high self-efficacious individuals believe that they have high coping abilities, and they can reduce their anxiety via actions that reduce the threat of environment. Accordantly, teachers' high self-efficacy accounted for their lower anxiety, predominately in secondary teaching level. The latter finding might hind that secondary school teachers stress their personal capabilities to handle the various demands of their professional role more than the primary school teachers, since the emotion of anxiety is associated to self- and the task (see Buss \& Hughes, 2007; Frenzel et al., 2009b). Also, experiencing emotions that are associated with others, such as low nervousness and low anger, perhaps, indicates the ability of the participants with a high sense of self-efficacy to face and overcome the difficulties that occur in their educational work, and develop a collaborative climate with colleagues, students, principals and parents (Caprara, Barbarenelli, Borgogni, Petitta et al., 2003; Dembo \& Gibson, 1985; Haniotakis \& Poulos, 2006; Hargreaves, 2001; Reyna \& Weiner, 2001; Rimm-Kaufman \& Sawyer, 2004; Stephanou \& Mastora, 2013; Sutton, 2000, 2007; Woolfolk et al., 1990). The low intensity of these emotions might be also rooted in teachers' judgment that they have the capability, as being high efficacious, to reach the desired professional goal (see Frenzel et al., 2009b; Lazarus \& Folkman, 1984; Smith \& Lazarus, 1993). Further, it seems that the primary school teaching level facilitates the specific emotional experiences. In a similar way, the efficacy perceptions proved formulator factor of the general emotions, such as happiness, pleasure and satisfaction, and context-related emotions, such as boredom, in agreement with previous studies (e.g., Klassen et al., 2009; Stephanou et al., 2013), showing that teachers with a high sense of self-efficacy can control their surroundings, function effectively in schools and enjoy task-involvement, such as classroom teaching (Bandura, 1997; Coladarci, 1992; Csikszentmihalyi, 1990; Evers et al., 2002; Gibson \& Dembo, 1984; Pajares \& Schunk, 2005; Pekrun, 2006; Pekrun et al., 2010; Stephanou et al., 2013; Wheatley, 2005; Wolters \& Daugherty, 2007). It is worth notably that boredom is associated with low achievement goals (e.g. Ainley, Corrigan, \& Richardson, 2005; Daniels, Stupnisky, Pekrun, Haynes, Perry, \& Newall, 2009).

Finally, the positive influential role of self-efficacy on the expectancy- and competent-dependent emotions, such as confidence, encouragement, hope and, mainly, competence might be rooted in the nature of self-efficacy which is a competence-based, prospective and optimistic construct, and it is rooted in ability, effort and motivation (see Bandura, 1997, 2006; Labone, 2004; Luszczynska \& Schwarzer, 2005; Ross et al., 1996; Tschannen-Moran \& Johnson, 2011; Wein- 
er, 2005).

The schema of the impact of efficacy beliefs on emotions indicates that the self-efficacy and collective efficacy are distinct concepts, and they complementary influence teacher emotional experience (see Bandura, 1982, 2001; Caprara, Barbarenelli, Borgogni, Petitta et al., 2003; Goddard, 2001; Goddard et al., 2000; Goddard et al., 2004; Stephanou et al., 2013).

Frenzel et al. (2009a, 2009b) proposed that the role of appraisal of coping potential in teacher emotions could be investigated in association to teacher self-efficacy beliefs. This study advanced that suggestion, by examining the inter-prediction of teaches' self-efficacy, collective-efficacy and problem-solving appraisal on their emotional experiences concerning school. As above mentioned, as all five components of problem-solving appraisal increased, the intensity of the positive emotions increased, and the intensity of the negative emotions decreased. However, the pattern changed when considered all the components as predictors in corporation with efficacy beliefs. Only reflective/approach style and confidence in solving the daily problems had direct effects beyond that of collective- and/or self-efficacy on the emotions of nervousness, calmness, anxiety, anger and enthusiasm. These findings complemented past researches that support the positive role of one's confidence and tendency to solve problems in anxiety, psychosocial adjustment and functionality, and self-esteem (see Endler et al., 2001; Heppner, 2008). It seems that the teachers with high sense of efficacy-efficacy estimated their ability to control negative emotional experiences as high, contributing to enhancement of positive emotions and reduction of negative emotional experience. In a such perspective, self-efficacy can be a mechanism of emotion regulation (see Goetz, Cronjaeger, Frenzel, Lüdtke, \& Hall, 2010). This was more evident in junior high school where getting high grades is the dominant goal, and the school subjects are considered difficult by the students (see Wolters \& Daugherty, 2007). Consequently, the high school teachers were more likely than the primary school teachers to appraise the status of self-factors in pursuing their goals. The task-specific measures of efficacy beliefs, in contrast to general measure of problem-solving appraisal, may be another explanation for the modest role of problem-solving appraisal in emotions. Research is needed to clarify under which conditions and tasks perceived ability to solve the problems affects emotional experiences in school.

\subsection{Implications of the Results in Practice and Future Research}

The findings from this study suggest that teachers' emotions relevant to their school constitute a significant aspect of their personal and professional life. It seems that teachers need to have a positive perspective to the variety of the school-related events, and a special ability to regulate and control their emotions. This implies the necessity of helping teachers to develop the necessary skills to recognize and regulate their own emotions, and, doing so, they are more likely to face the challenges that may be present in the variety of school contexts. 
The results from the present investigation suggest that efficacy beliefs and problem-solving appraisal are antecedents of teacher emotions, and both constructs may permit the regulation of emotions. Programmes, based in socio-cognitive theory, along within socio-cultural grounding, may help problematic school communities by strengthening teachers' self-efficacy and problem-solving.

The emotion scheme and its link to problem-solving appraisal and efficacy beliefs proved complicative. The findings were interpreted with respect to school constituencies, interpersonal relations and personal-factors. Future research needs to explicitly specify the sources of the teachers' emotions and how they are interrelated to the rest of the examined factors. Research is also needed to examine teacher-student emotions, and the consequences for future relationships, achievement, social behavior and emotions. Furthermore, to overcome the limitations of this study, such as collecting data once at a school year, examining emotional experience referred generally to school and focusing only in state schools, investigation is necessary to gather data during the whole school year, in specific academic domains and various school contexts, in both genders. In addition to self-report measures that the present research applied, subjective measures and diary could be applied in further investigation.

Overall, this study contributes into research and practice that may help teachers to have a mindfully professional life and become effective professions, by addressing emotions and the antecedents of the emotions that are related to self, context and self-context interaction.

\section{References}

Acee, T. W., Kim, H., Kim, H. J., Kim, J., Kim, J.-I., Chu, H-N., R., Kim, M., Cho, Y., \& Wicker, F. W. (2010). Academic Boredom in Under- and Over-Challenging Situations. Contemporary Educational Psychology, 35, 17-27. https://doi.org/10.1016/j.cedpsych.2009.08.002

Adams, C. M., \& Forsyth, P. B. (2006). Proximate Sources of Collective Teacher Efficacy. Journal of Educational Administration, 44, 625-642. https://doi.org/10.1108/09578230610704828

Ainley, M., Corrigan, M., \& Richardson, N. (2005). Students, Tasks, and Emotions: Identifying the Contribution of Emotions to Students' Reading of Popular Culture and Popular Science Texts. Learning and Instruction, 15, 433-447. https://doi.org/10.1016/j.learninstruc.2005.07.011

Aloe, A., Amo, L., \& Shanahan, M. (2014). Classroom Management Self-Efficacy and Burnout: A Multivariate Meta-Analysis. Educational Psychology Review, 26, 101-126. https://doi.org/10.1007/s10648-013-9244-0

Anderson, R. N., Greene, M. L., \& Loewen, P. S. (1988). Relationships among Teachers' and Students' Thinking Skills, Sense of Efficacy, and Student Achievement. Alberta Journal of Educational Research, 34, 148-165. https://doi.org/10.1016/S1053-4822(02)00047-5

Ashforth, B. E., \& Kreiner, G. E. (2002). Normalizing Emotion in Organizations: Making the Extraordinary Seem Ordinary. Human Resource Management Review, 12, 215-235.

Ashton, P. T., \& Webb, R. B. (1986). Making a Difference: Teachers' Sense of Efficacy and 
Student Achievement. New York: Longman.

Atik, G., \& Erkan, Z. (2009). Academic Self-Efficacy and Problem Solving as Predictors of Hope Levels of Turkish High School Students. Austria, Vienna.

Austin, J. (2012). On the Alignment of Pre-Service Teachers' Personal Mathematics Teacher Efficacy Beliefs and Mathematical Knowledge for Teaching (Unpublished Doctoral Dissertation). University of Delaware.

Austin, J. (2013). The Role of Contextual Factors in Understanding Mathematics Teacher Efficacy Beliefs. Journal of Mathematical Sciences and Mathematics Education, 8, 46-60.

Avanzi, L., Miglioretti, M., Velasco, V., Balducci, C., Vecchio, L., Fraccaroli, F., \& Skaalvik, E. (2013). Cross-Validation of the Norwegian Teacher's Self-Efficacy Scale (NTSES). Teaching and Teacher Education, 31, 69-78. https://doi.org/10.1016/j.tate.2013.01.002

Baker, D. F. (2001). The Development of Collective Efficacy in Small Task Groups. Small Group Research, 32, 451-474. https://doi.org/10.1177/104649640103200404

Bakker A. B. (2005). Flow among Music Teachers and Their Students: The Crossover of Peak Experiences. Journal of Vocational Behavior, 66, 26-44. https://doi.org/10.1016/j.jvb.2003.11.001

Bandura A. (1993). Perceived Self-Efficacy in Cognitive Development and Functioning. Educational Psychologist, 28, 117-148. https://doi.org/10.1207/s15326985ep2802_3

Bandura, A. \& Locke, E. A. (2003). Negative Self-Efficacy and Goal Effects Revisited. Journal of Applied Psychology, 88, 87-99. https://doi.org/10.1037/0021-9010.88.1.87

Bandura, A. (1982). Self-Efficacy Mechanism in Human Agency. American Psychologist, 37, 122-147. https://doi.org/10.1037/0003-066X.37.2.122

Bandura, A. (1986). Social Foundations of Thought and Action. New York: Prentice-Hall.

Bandura, A. (1997). Self-Efficacy: The Exercise of Control. New York: Freeman.

Bandura, A. (2001). Social Cognitive Theory: An Agentic Perspective. Annual Review of Psychology, 52, 1-26. https://doi.org/10.1146/annurev.psych.52.1.1

Bandura, A. (2006). Guide for Constructing Self-Efficacy Scales. In F. Pajares, \& T. Urdan (Eds.), Adolescence and Education: Self Efficacy and Adolescence (pp. 307-337). Greenwich, CT: Information Age.

Bandura, A., Taylor, C. B., Williams, S. L., Mefford, I. N., \& Barchas, J. D. (1985). Catecholamine Secretion as a Function of Perceived Coping Self-Efficacy. Journal of Consulting and Clinical Psychology, 53, 406-414.

https://doi.org/10.1037/0022-006X.53.3.406

Barrett, L. F., Lindquist, K. A., Bliss-Moreau, E., Duncan, S., Gendron, M., Mize, J., \& Brennan, L. (2007). Of Mice and Men: Natural Kinds of Emotions in the Mammalian Brain? A Response to Panksepp and Izard. Perspectives on Psychological Science, 2, 297-311. https://doi.org/10.1111/j.1745-6916.2007.00046.x

Battistich, V., Solomon, D., Watson, M., Solomon, J., \& Schaps, E. (1989). Effects of an Elementary School Program to Enhance Prosocial Behavior on Children's Cognitive-Social Problem-Solving Skills and Strategies. Journal of Applied Developmental Psychology, 10, 147-169. https://doi.org/10.1016/0193-3973(89)90002-6

Baumgardner, A. H., Heppner, P. P., \& Arkin, R. M. (1986). Role of Causal Attribution in Personal Problem Solving. Journal of Personality and Social Psychology, 50, 636-643. https://doi.org/10.1037/0022-3514.50.3.636

Beach, R., \& Pearson, D. (1998). Changes in Preservice Teachers' Perceptions of Conflicts and Tensions. Teaching and Teacher Education, 14, 337-351. 
https://doi.org/10.1016/S0742-051X(97)00041-3

Becker, E. S., Goetz, T., Morger, V., \& Ranellucci, J. (2014). The Importance of Teachers' Emotions and Instructional Behavior for Their Students' Emotions-An Experience Sampling Analysis. Teaching and Teacher Education, 43, 15-26. https://doi.org/10.1016/j.tate.2014.05.002

Becker, E. S., Keller, M. M., Goetz, T., Frenzel, E. C., \& Taxer, J. L. (2015). Antecedents of Teachers' Emotions in the Classroom: An Intraindividual Approach. Front Psychology, 6, 635. https://doi.org/10.3389/fpsyg.2015.00635

Beilock, S. L., Gunderson, E. A., Ramirez, G., \& Levine, S. C. (2010). Female Teachers' Math Anxiety Affects Girls' Math Achievement. Proceedings of the National Academy of Sciences, 107, 1060-1063. https://doi.org/10.1073/pnas.0910967107

Betoret, F. D. (2006). Stressors, Self-Efficacy, Coping Resources, and Burnout among Secondary School Teachers in Spain. Educational Psychology: An International Journal of Experimental Educational Psychology, 26, 519-539. https://doi.org/10.1080/01443410500342492

Betoret, F., \& Artiga, A. (2010). Barriers Perceived by Teachers at Work, Coping Strategies, Self-Efficacy and Burnout. The Spanish Journal of Psychology, 13, 637-654. https://doi.org/10.1017/S1138741600002316

Blankstein, K. R., Flett, G. L., \&Watson, M. S. (1992). Coping and Academic Problem-Solving Ability in Test Anxiety. Journal of Clinical Psychology, 48, 37-46. https://doi.org/10.1002/1097-4679(199201)48:1\%3C37::AID-JCLP2270480105\%3E3.0. $\mathrm{CO} ; 2-\mathrm{F}$

Blase, J. J. (1986). A Qualitative Analysis of Sources of Teacher Stress: Consequences for Performance. American Educational Research Journal, 23, 13-40. https://doi.org/10.3102/00028312023001013

Boekaerts, M. (2007). Understanding Students' Affective Processes in the Classroom. In P. Schutz, R. Pekrun, \& G. Phye (Eds), Emotion in Education (pp. 37-56). San Diego, CA: Academic Press. https://doi.org/10.1016/B978-012372545-5/50004-6

Boekaerts, M., \& Corno, L. (2005). Self-Regulation in the classroom. Applied Psychology, 54, 199-231. https://doi.org/10.1111/j.1464-0597.2005.00205.x

Boiger, M., \& Mesquita, B. (2012). The Construction of Emotion in Interactions, Relationships, and Cultures. Emotion Review, 4, 221-229. https://doi.org/10.1177/1754073912439765

Bong, M., \& Skaalvik, E. M. (2003). Academic Self-Concept and Self-Efficacy: How Different Are They Really? Educational Psychology Review, 15, 1-40. https://doi.org/10.1023/A:1021302408382

Brackett, M. A., Floman, J. L., Ashton-James, C., Cherkasskiy, L., \& Salovey, P. (2013). The Influence of Teacher Emotion on Grading Practices: A Preliminary Look at the Evaluation of Student Writing. Teachers and Teaching: Theory and Practice, 19, 634-646.

Brígido, M., Borrachero, A., Bermejo, M., \& Mellado, V. (2013). Prospective Primary Teachers' Self-Efficacy and Emotions in Science Teaching. European Journal of Teacher Education, 36, 200-217. https://doi.org/10.1080/02619768.2012.686993

Brinson, D., \& Steiner, L. (2007). Building Collective Efficacy: How Leaders Inspire Teachers to Achieve (Issue Brief). Washington, DC: Center for Comprehensive School Reform and Improvement.

Brouwers, A., \& Tomic, W. (2000). A Longitudinal Study of Teacher Burnout and Perceived Self-Efficacy in Classroom Management. Teaching and Teacher Education, 15, 
239-253. https://doi.org/10.1016/S0742-051X(99)00057-8

Brown, C. G. (2012). A Systematic Review of the Relationship between Self-Efficacy and Burnout in Teachers. Educational and Child Psychology, 29, 47-63.

Buss, M. T., \& Hughes, J. N. (2007). Teachers' Attitudes toward Emotions Predict Implementation of and Satisfaction with a Social-Emotional Curriculum. Washington DC: Society for Prevention Research.

Caprara, G. V., Barbaranelli, C., Borgogni, I., Petitta, I., \& Rubinacci, A. (2003). Teachers', School Staff's and Parents' Efficacy Beliefs as Determinants of Attitude toward School. European Journal of Psychology of Education, 18, 15-31. https://doi.org/10.1007/BF03173601

Caprara, G. V., Barbaranelli, C., Borgogni, L., \& Steca, P. (2003). Efficacy Beliefs as Determinants of Teachers' Job Satisfaction. Journal of Educational Psychology, 95, 821-832. https://doi.org/10.1037/0022-0663.95.4.821

Caprara, G. V., Barbaranelli, C., Steca, P., \& Malone, P. S. (2006). Teachers' Self-Efficacy Beliefs as Determinants of Job Satisfaction and Students' Academic Achievement: A Study at the School Level. Journal of School Psychology, 44, 473-490.

https://doi.org/10.1016/j.jsp.2006.09.001

Carscaddon, D. M., Poston, J., \& Sachs, E. (1988). Problem-Solving Appraisal as It Relates to State-Trait Personality Factors. A Journal of Human Behavior, 25, 73-76.

Carver, C. S., Scheier, M. F., \& Weintraub, J. K. (1989). Assessing Coping Strategies: A Theoretically Based Approach. Journal of Personality and Social Psychology, 56, 267-283. https://doi.org/10.1037/0022-3514.56.2.267

Carver, C., \& Connor-Smith, J. (2010). Personality and Coping. Annual Review of Psychology, 61, 679-704. https://doi.org/10.1146/annurev.psych.093008.100352

Chang M.-L., \& Davis H. A. (2009). Understanding the Role of Teacher Appraisals in Shaping the Dynamics of Their Relationships with Students: Deconstructing Teachers' Judgments of Disruptive Behavior/Students. In P. A. Schutz, \& M. Zembylasb (Eds.), Advances in Teacher Emotions Research: The Impact on Teachers Lives (pp. 95-127). New York: Springer.

Chang, M.-L. (2009). An Appraisal Perspective of Teacher Burnout: Examining the Emotional Work of Teachers. Educational Psychology Review, 21, 193-218.

https://doi.org/10.1007/s10648-009-9106-y

Chang, M.-L. (2013). Toward a Theoretical Model to Understand Teacher Emotions and Teacher Burnout in the Context of Student Misbehavior: Appraisal, Regulation and Coping. Motivation and Emotion, 37, 799-817. https://doi.org/10.1007/s11031-012-9335-0

Chen, J. (2016). Understanding Teacher Emotions: The Development of a Teacher Emotion. Teaching and Teacher Education, 55, 68-77. https://doi.org/10.1016/j.tate.2016.01.001

Chernack, G. M. (2011). Student Attribution of Teacher Affect in Contexts of Behavioral and Academic Failure (Unpublished Dissertation, Fordham University).

Cheung, F. M. (2000). Deconstructing Counseling in a Cultural Context. The Counseling Psychologist, 28, 123-132. https://doi.org/10.1177/0011000000281008

Chwalisz, K., Altmaier, E. M., \& Russell, D. W. (1992). Causal Attributions, Self-Efficacy Cognitions, and Coping with Stress. Journal of Social and Clinical Psychology, 11, 377-400. https://doi.org/10.1521/jscp.1992.11.4.377

Cohen, J. B., Pham, M. T., \& Andrade, E. B. (2008). The Nature and Role of Affect in Consumer Behavior. In C. P. Haugtvedt, P. M. Herr, \& F. R. Kardes (Eds.), Marketing 
and Consumer Psychology Series: Handbook of Consumer Psychology (Vol. 4, pp. 297-348). New York: Taylor \& Francis.

Coladarci, T. (1992). Teachers' Sense of Efficacy and Commitment to Teaching. Journal of Experimental Education, 60, 323-337. https://doi.org/10.1080/00220973.1992.9943869

Collie, R. J., Shapka, J. D., \& Perry, N. E. (2012). School Climate and Social-Emotional Learning Predicting Teacher Stress, Job Satisfaction, and Teaching Efficacy. Journal of Educational Psychology, 104, 1189-1204. https://doi.org/10.1037/a0029356

Cornelius-White, J. (2007). Learner-Centered Teacher-Student Relationships Are Effective: A Meta-Analysis. Review of Educational Research, 77, 113-143. https://doi.org/10.3102/003465430298563

Csikszentmihalyi, M. (1990). Flow: The Psychology of Optimal Experience. New York: Harper Collins.

D’Zurilla, T. J. (1986). Problem-Solving Therapy: A Social Competence Approach to Clinical Intervention. New York: Springer.

D'Zurilla, T. J., \& Nezu, A. M. (1999). Problem Solving Therapy: A Social Competence Approach to Clinical Intervention (2nd ed.). New York: Springer.

D’Zurilla, T. J., \& Nezu, A. M. (2010). Problem-Solving Therapy. In K. S. Dobson (Ed.), Handbook of Cognitive-Behavioral Therapies (pp. 197-225). New York: Guilford Press.

D’Zurilla, T. J., Nezu, A. M., \& Maydeu-Olivares, A. (2004). Social Problem Solving: Theory and Assessment. In E. C. Chang, T. J. D'Zurilla, \& L. J. Sanna (Eds.), Social Problem Solving: Theory, Research, and Training (pp. 202-274). Washington DC: American Psychological Association. https://doi.org/10.1037/10805-001

Daniels, L. M., Stupnisky, R. H., Pekrun, R., Haynes, T. L., Perry, R. P., \& Newall, N. E. (2009). A Longitudinal Analysis of Achievement Goals: From Affective Antecedents to Emotional Effects and Achievement Outcomes. Journal of Educational Psychology, 101, 948-963. https://doi.org/10.1037/a0016096

Darby, A. (2008). Teachers' Emotions in the Reconstruction of Professional Self-Understanding. Teaching and Teacher Education, 24, 1160-1172. https://doi.org/10.1016/j.tate.2007.02.001

Davis, H. A. (2003). Conceptualizing the Role and Influence of Student-Teacher Relationship on Children's Social and Cognitive Development. Educational Psychologist, 38, 207-234. https://doi.org/10.1207/S15326985EP3804_2

Davis, H. A., DiStefano, C., \& Schutz, P. A. (2008). Identifying Patterns of Appraising Tests in First Year College Students: Implications for Anxiety and Emotion Regulation during Test Taking. Journal of Educational Psychology, 100, 942-960. https://doi.org/10.1037/a0013096

Day, C., \& Qing, G. (2009). Teachers' Emotions: Well-Being and Effectiveness. In P. A. Schutz, \& M. Zembylas (Eds.), Advances in Teacher Emotions Research: The Impact on Teachers Lives (pp. 15-32). New York: Springer.

Dembo, M. H., \& Gibson, S. (1985). Teachers' Sense of Efficacy: An Important Factor in School Improvement. Elementary School Journal, 86, 173-184.

https://doi.org/10.1086/461441

Demetriou, H., Wilson, E., \& Winterbottom, M. (2009). The Role of Emotion in Teaching: Are There Differences between Male and Female Newly Qualified Teachers' Approaches to Teaching? Educational Studies, 35, 449-473.

https://doi.org/10.1080/03055690902876552

Demir, K. (2008). Transformational Leadership and Collective Efficacy: The Moderating 
Roles of Collaborative Culture and Teachers' Self-Efficacy. Eurasian Journal of Educational Research, 33, 93-112.

Deniz, M. E. (2004). Investigation of the Relation between Decision Self-Esteem, Decision Making Style and Problem-Solving Skill of the University Students. Eurasian Journal of Educational Research, 4, 23-35.

Efklides, A. (2006). Metacognition and Affect: What Can Metacognitive Experiences Tell Us about the Learning Process? Educational Research Review, 1, 3-14. https://doi.org/10.1016/j.edurev.2005.11.001

Efklides, A. (2011). Interactions of Metacognition with Motivation and Affect in Self-Regulated Learning: The MASRL Model. Educational Psychologist, 46, 6-25. https://doi.org/10.1080/00461520.2011.538645

Efklides, A., \& Volet, S., Eds. (2005). Feelings and Emotions in the Learning Process (Special Issue). Learning and Instruction, 15, 377-515. https://doi.org/10.1016/j.learninstruc.2005.07.006

Eid, M., \& Diener, E. (2004). Global Judgments of Subjective Well-Being Situational Variability and Long-Term Stability. Social Indicators Research, 65, 245-277. https://doi.org/10.1023/B:SOCI.0000003801.89195.bc

Elliot, T. R., Shewchuk, R., Hagglund, K., Rybarczyk, B., \& Harkins, S. (1996). Occupational Burnout, Tolerance for Stress, and Coping among Nurses in Rehabilitation Units. Rehabilitation Psychology, 41, 267-284. https://doi.org/10.1037/0090-5550.41.4.267

Elliot, T., Godshall, F., Shrout, J., \& Witty, T. (1990). Problem-Solving Appraisal, Self-Reported Study Habits, and Performance of Academically At-Risk College Students. Journal of Counseling Psychology, 37, 203-207.

https://doi.org/10.1037/0022-0167.37.2.203

Elliott, T. R., Godshall, F. J., Herrick, S. M., Witty, T. E., \& Spruell, M. (1991). Problem-Solving Appraisal and Psychological Adjustment Following Spinal Cord Injury. Cognitive Therapy and Research, 15, 387-398. https://doi.org/10.1007/BF01173033

Elliott, T. R., Herrick, S. M., \&Witty, T. E. (1992). Problem-Solving Appraisal and the Effects of Social Support among College Students and Persons with Physical Disabilities. Journal of Counseling Psychology, 39, 219-226. https://doi.org/10.1037/0022-0167.39.2.219

Ellsworth, P. C., \& Scherer, K. R. (2003). Appraisal Processes in Emotion. In R. J. Davidson, \& K. R. Scherer (Eds.), Handbook of Affective Sciences (pp. 572-596). Oxford: Oxford University Press.

Emmer, E. T. (1994). Teacher Emotions and Classroom Management. New Orleans, LA: Annual Meeting of the American Educational Research Association.

Endler, N. S., Kocovski, N. L., \& Macrodimitris, S. D. (2001). Copping, Efficacy, and Perceived Control in Acute vs Chronic Illnesses. Personality and Individual Differences, 30, 617-625. https://doi.org/10.1016/S0191-8869(00)00060-X

Erb, C. S. (2002). The Emotional Whirlpool of Beginning Teachers' Work. Canada, Toronto: Annual Meeting of the Canadian Society of Studies in Education.

Erozkan, A. (2013). The Effect of Communication Skills and Interpersonal Problem-Solving Skills on Social Self-Efficacy. Educational Sciences: Theory \& Practice, 13, 739-745.

Evers, W. J. G., Brouwers, A., \& Tomic, W. (2002). Burnout and Self-Efficacy: A Study on Teachers' Beliefs When Implementing an Innovative Educational System in the Netherlands. British Journal of Educational Psychology, 72, 227-243. 
https://doi.org/10.1348/000709902158865

Felton, G. M., Parsons, M. A., \& Bartoces, M. G. (1997). Demographic Factors: Interaction Effects on Health-Promoting Behavior and Health Related Factors. Public Health Nursing, 14, 361-367. https://doi.org/10.1111/j.1525-1446.1997.tb00305.x

Fernández-Ballesteros, R., Díez-Nicolás, J., Caprara, G. V., Barbaranelli, C., \& Bandura, A. (2002). Determinants and Structural Relation of Personal Efficacy to Collective Efficacy. Applied Psychology: An International Review, 51, 107-125. https://doi.org/10.1111/1464-0597.00081

Fiori, K. L., McIlvane, J. M., Brown, E. E., \& Antonucci, T. C. (2006). Social Relations and Depressive Symptomatology: Self-Efficacy as a Mediator. Aging \& Mental Health, 10, 227-239. https://doi.org/10.1080/13607860500310690

Fives, H. (2003). What Is Teacher Efficacy and How Does It Relate to Teachers' Knowledge? A Theoretical Review. Chicago, USA: American Educational Research Association Annual Conference.

Folkman, S., \& Lazarus, R. S. (1988). The Relationship between Coping and Emotion: Implications for Theory and Research. Social Science Medicine, 26, 309-317. https://doi.org/10.1016/0277-9536(88)90395-4

Folkman, S., Lazarus, R. S., Dunkel-Schetter, C., DeLongis, A., \& Gruen, R. J. (1986). Dynamics of a Stressful Encounter: Cognitive Appraisal, Coping, and Encounter Outcomes. Journal of Personality and Social Psychology, 50, 992-1003. https://doi.org/10.1037/0022-3514.50.5.992

Fredrickson, B. L. (2001). The Role of Positive Emotions in Positive Psychology: The Broaden-and-Build Theory of Positive Emotions. American Psychologist, 56, 218-226. https://doi.org/10.1037/0003-066X.56.3.218

Fredrickson, B. L., \& Branigan, C. (2005). Positive Emotions Broaden the Scope of Attention and Thought-Action Repertoires. Cognition and Emotion, 19, 313-332. https://doi.org/10.1080/02699930441000238

Frenzel, A. C., Gotz, T., Stephens, E. J., \& Jacob, B. (2009b). Antecedents and Effects of Teachers' Emotional Experiences: An Integrative Perspective and Empirical Test, In P. A. Schutz, \& M. Zembylas (Eds.), Advances in Teacher Emotions Research: The Impact on Teachers Lives (pp. 129-148). New York: Springer.

Frenzel, A. C., \& Goetz, T. (2007). Emotionales Erleben von Lehrkräften beim Unterrichten. Zeitschrift für Pädagogische Psychologie, 21, 283-295.

https://doi.org/10.1024/1010-0652.21.3.283

Frenzel, A. C. (2014). Teacher Emotions. In: R. Pekrun, \& A. Linnenbrink (Eds.), International Handbook of Emotions in Education (pp. 494-519). New York: Routledge.

Frenzel, A. C., Goetz, T., Lüdtke, O., Pekrun, R., \& Sutton, R. E. (2009a). Emotional Transmission in the Classroom: Exploring the Relationships between Teacher and Student Enjoyment. Journal of Educational Psychology, 101, 705-716. https://doi.org/10.1037/a0014695

Fried, L., Mansfield, C., \& Dobozy, E. (2015). Teacher Emotion Research: Introducing a Conceptual Model to Guide Future Research. Issues in Educational Research, 25, 415-441.

Frijda, N. H. (2009). Emotions, Individual Differences, and Time Course: Reflections. Cognition and Emotion, 23, 1444-1461. https://doi.org/10.1080/02699930903093276

Furrer, C., \& Skinner, E. (2003). Sense of Relatedness as a Factor in Children's Academic Engagement and Performance. Journal of Educational Psychology, 95, 148-162. https://doi.org/10.1037/0022-0663.95.1.148

Gibson, S., \& Dembo, M. (1984). Teacher Efficacy: A Construct Validation. Journal of 
Educational Psychology, 76, 569-582. https://doi.org/10.1037/0022-0663.76.4.569

Gilbert, R. B., Adesope, O. O., \& Schroeder, N. L. (2014). Efficacy Beliefs, Job Satisfaction, Stress and Their Influence on the Occupational Commitment of English-Medium Content Teachers in the Dominican Republic. Educational Psychology, 34, 876-899. https://doi.org/10.1080/01443410.2013.814193

Gill, M. G., \& Hardin, C. (2015). A “Hot” Mess: Unpacking the Relation between Teachers' Beliefs and Emotions. In H. Fives, \& M. G. Gill (Eds.), International Handbook of Research on Teachers' Beliefs (pp. 230-245). New York, NY: Routledge.

Goddard, R. D. (2001). Collective Efficacy: A Neglected Construct in the Study of Schools and Student Achievement. Journal of Educational Psychology, 93, 467-476. https://doi.org/10.1037/0022-0663.93.3.467

Goddard, R. D. (2002). Collective Efficacy and School Organization: A Multilevel Analysis of Teacher Influence in Schools. Theory and Research in Educational Administration, 1, 169-184.

Goddard, R. D., Hoy, W. K., \& Woolfolk Hoy, A. (2000). Collective Efficacy: Its Meaning, Measure, and Impact on Student Achievement. American Educational Research Journal, 37, 479-507. https://doi.org/10.3102/00028312037002479

Goddard, R. D., Hoy, W. K., \& Woolfolk Hoy, A. (2004). Collective Efficacy Beliefs: Theoretical Developments, Empirical Evidence, and Future Directions. Educational Researcher, 33, 3-13. https://doi.org/10.3102/0013189X033003003

Goddard, R., \& Goddard, M. (2006). Beginning Teacher Burnout in Queensland Schools: Associations with Serious Intentions to Leave. The Australian Educational Researcher, 33, 61-75. https://doi.org/10.1007/BF03216834

Goetz, T., Cronjaeger, H., Frenzel, A. C., Lüdtke, O., \& Hall, N. C. (2010). Academic Self-Concept and Emotion Relations: Domain Specificity and Age Effects. Contemporary Educational Psychology, 35, 44-58. https://doi.org/10.1016/j.cedpsych.2009.10.001

Grant, H., \& Higgins, E. T. (2003). Optimism, Promotion Pride, and Prevention Pride as Predictors of Quality of Life. Personality and Social Psychology Bulletin, 29, 1521-1532. https://doi.org/10.1177/0146167203256919

Greenwood, G. E., Olejnik, S. F., \& Parkay, F. W. (1990). Relationships between Four Teacher Efficacy Belief Patterns and Selected Teacher Characteristics. Journal of Research and Development in Education, 23, 102-106.

Guskey, T. R. (1987). Context Variables That Affect Measures of Teacher Efficacy. The Journal of Educational Research, 81, 41-47. https://doi.org/10.1080/00220671.1987.10885795

Hagenauer, G., Hascher, T., \& Volet, S. E. (2015). Teacher Emotions in the Classroom: Associations with Students' Engagement, Classroom Discipline and the Interpersonal Teacher-Student Relationship. European Journal of Psychology of Education, 30, 385-403. https://doi.org/10.1007/s10212-015-0250-0

Haniotakis, N., \& Poulos, M. (2006). Instructive and Emotional Dimensions of Teaching: Perceptions of Prospective Teachers. Scientific Annals of Psychological Society of Northern Greece, 4, 141-174.

Hargreaves, A. (2000). Mixed Emotions: Teachers' Perceptions of Their Interactions with Students. Teaching and Teacher Education, 16, 811-826. https://doi.org/10.1016/S0742-051X(00)00028-7

Hargreaves, A. (2001). Emotional Geographies of Teaching. Teachers College Record, 103, 1056-1080. https://doi.org/10.1111/0161-4681.00142

Hargreaves, A. (2004). Inclusive and Exclusive Educational Change: Emotional Responses of Teachers and Implications for Leadership. School Leadership \& Management, 24, 
287-309. https://doi.org/10.1080/1363243042000266936

Hargreaves, A. (2005). The Emotions of Teaching and Educational Change. In A. Hargreaves (Ed.), Extending Educational Change (pp. 278-295). Amsterdam: Springer. https://doi.org/10.1007/1-4020-4453-4_14

Hargreaves, A., \& Tucker, B. (1991). Teaching and Guilt: Exploring the Emotions of Teaching. Teaching and Teacher Education, 7, 491-505. https://doi.org/10.1016/0742-051X(91)90044-P

Hass, J. C. (2005). A Case Study of the Actions Taken by a School District in Planning and Implementing a Strategy to Establish School-Based Professional Learning Communities (Doctoral Dissertation). University of Maryland.

Heppner, P. P. (2008). Expanding the Conceptualization and Measurement of Applied Problem Solving and Coping: From Stages to Dimensions to the Almost Forgotten Cultural Context. American Psychologist, 63, 805-816. https://doi.org/10.1037/0003-066X.63.8.805

Heppner, P. P., \& Baker, C. E. (1997). Applications of the Problem Solving Inventory. Measurement and Evaluation in Counseling and Development, 29, 229-241.

Heppner, P. P., \& Krauskopf, C. J. (1987). An Information Processing Approach to Personal Problem Solving. The Counseling Psychologist, 15, 371-447. https://doi.org/10.1177/0011000087153001

Heppner, P. P., \& Lee, D. G. (2002). Problem Solving Appraisal and Psychological Adjustment. In C. R. Snyder, \& S. J. Lopez (Eds.), Handbook of Positive Psychology (PP. 288-298). New York: Oxford University Press.

Heppner, P. P., \& Petersen, C. H. (1982). The Development and Implications of a Personal Problem-Solving Inventory. Journal of Counseling Psychology, 29, 66-75. https://doi.org/10.1037/0022-0167.29.1.66

Heppner, P. P., Cooper, C. C., Mulholland, A. M., \& Wei, M. F. (2001). A Brief, Multidimensional, Problem-Solving Based Psychotherapy Outcome Measure. Journal of Counseling Psychology, 48, 330-343. https://doi.org/10.1037/0022-0167.48.3.330

Heppner, P. P., Lee, D.-G., Wei, M., Anderson, C., \& Wang, Y.-W. (2001). Does Negative Affectivity Confound the Problem Solving-Psychological Adjustment Link? San Francisco: The 109th Annual Convention of the American Psychological Association.

Heppner, P. P., Pretorius, T. B., Wei, M., Lee, D.-G., \& Wang, Y. W. (2002). Examining the Generalizability of Problem Solving Appraisal in Black South Africans. Journal of Counseling Psychology, 49, 484-498. https://doi.org/10.1037/0022-0167.49.4.484

Heppner, P. P., Witty, T. E., \& Dixon, W. A. (2004). Problem-Solving Appraisal and Human Adjustment: A Review of 20 Years of Research Using the Problem Solving Inventory. The Counseling Psychologist, 32, 344-428.

https://doi.org/10.1177/0011000003262793

Heppner, P., Lee, D., \& Tian, L. (2009). Problem-Solving Appraisal and Psychological Adjustment. In S. J. Lopez, \& C. R. Snyder (Eds.), The Oxford Handbook of Positive Psychology (2nd Ed., pp. 588-598). Oxford: Oxford University Press. https://doi.org/10.1093/oxfordhb/9780195187243.013.0032

Holzberger, D., Philipp, A., \& Kunter, M. (2013). How Teachers' Self-Efficacy Is Related to Instructional Quality: A Longitudinal Analysis. Journal of Educational Psychology, 105, 774-789. https://doi.org/10.1037/a0032198

Hoy, A. W., Davis, H., \& Pape, S. J. (2006). Teacher Knowledge and Beliefs. In P. A. Alexander, \& P. H. Winne (Eds.), Handbook of Educational Psychology (2nd Ed., pp. 715-737). Mahwah, NJ: Lawrence Erlbaum. 
Hoy, A., \& Spero, R. B. (2005). Changes in Teacher-Efficacy during the Early Years of Teaching: A Comparison of Four Measures. Teaching and Teacher Education, 21, 343-356.

Hoy, W. K., \& Miskel, C. G. (2008). Educational Administration: Theory, Research, and Practice (8th Ed.). New York: McGraw-Hill.

Isen, A. M. (1993). Positive Affect and Decision Making. In M. Lewis, \& J. M. Haviland, (Eds.), Handbook of Emotions (pp. 261-277). New York: Guilford Press.

Isen, A. M. (2001). An Influence of Positive Affect on Decision Making in Complex Situations: Theoretical Issues with Practical Implications. Journal of Consumer Psychology, 11, 75-85. https://doi.org/10.1207/S15327663JCP1102_01

Isen, A. M. (2008). Positive Affect and Decision Processes: Some Recent Theoretical Developments with Practical Implications. In C. P. Haugtvedt, P. M. Herr, \& F. R. Kardes (Eds.), Handbook of Consumer Psychology (pp. 273-348). New York: Psychology Press.

Izard, C. (2007). Basic Emotions, Natural Kinds, Emotion Schemas, and a New Paradigm. Perspectives on Psychological Science, 2, 260-280.

Jennings, P. A., \& Greenberg, M. T. (2009). The Prosocial Classroom: Teacher Social and Emotional Competence in Relation to Student and Classroom Outcomes. Review of Educational Research, 79, 491-525. https://doi.org/10.3102/0034654308325693

Jerusalem, M., \& Hessling, J. (2009). Mental Health Promotion in Schools by Strengthening Self-Efficacy. Health Education, 109, 329-341. https://doi.org/10.1108/09654280910970901

Jesus, S., \& Lens, W. (2005). An Integrated Model for the Study of Teacher Motivation. Applied Psychology: An International Review, 54, 119-134. https://doi.org/10.1111/j.1464-0597.2005.00199.x

Karademas, E. C., \& Kalantzi-Azizi, A. (2004). The Stress Process, Self-Efficacy Expectations, \& Psychological Health. Personality and Individual Differences, 37, 1033-1043. https://doi.org/10.1016/j.paid.2003.11.012

Katz-Navon, T., \& Erez, M. (2005). When Collective and Self-Efficacy Affect Team Performance. The Role of Task Interdependence. Small Group Research, 36, 437-465. https://doi.org/10.1177/1046496405275233

Kelchtermans, G. (2005). Teachers' Emotions in Educational Reforms: Self-Understanding, Vulnerable Commitment and Micropolitical Literacy. Teaching and Teacher Education, 21, 995-1006. https://doi.org/10.1016/j.tate.2005.06.009

Keller, M. M., Chang, M. L., Becker, E. S., Goetz, T., \& Frenzel, A. C. (2014). Teachers' Emotional Experiences and Exhaustion as Predictors of Emotional Labor in the Classroom: An Experience Sampling Study. Front Psychology, 5, 1442. https://doi.org/10.3389/fpsyg.2014.01442

Keller, M. M., Goetz, T., Becker, E. S., Morger, V., \& Hensley, L. (2014). Feeling and Showing: A New Conceptualization of Dispositional Teacher Enthusiasm and Its Relation to Students' Interest. Learning and Instruction, 33, 29-38.

https://doi.org/10.1016/j.learninstruc.2014.03.001

Keller, M. M., Woolfolk Hoy, A. E., Goetz, T., \& Frenzel, A. C. (2016). Teacher Enthusiasm: Reviewing and Redefining a Complex Construct. Educational Psychology Review, 28, 743-769. https://doi.org/10.1007/s10648-015-9354-y

Kimura, Y. (2010). Expressing Emotions in Teaching: Inducement, Suppression, and Disclosure as Caring Profession. Educational Studies in Japan: International Yearbook, 5, 63-78.

Klassen, R. M., \& Chiu, M. M. (2010). Effects on Teachers' Self-Efficacy and Job Satisfac- 
tion: Teacher Gender, Years of Experience, and Job Stress. American Psychological Association, 102, 741-756.

Klassen, R. M., Bong, M., Usher, E. L., Chong, W. H., Huan, V. S., Wong, I. Y., \& Georgiou, T. (2009). Exploring the Validity of the Teachers' Self-Efficacy Scale in Five Countries. Contemporary Educational Psychology, 34, 67-76. https://doi.org/10.1016/j.cedpsych.2008.08.001

Klassen, R. M., Usher, E. L., \& Bong, M. (2010). Teachers' Collective Efficacy, Job Satisfaction, and Job Stress in Cross-Cultural Context. Journal of Experimental Education, $78,464-486$.

Knoll, N., Rieckmann, N., \& Schwarzer, R. (2005). Coping as a Mediator between Personality and Stress Outcomes: A Longitudinal Study with Cataract Surgery Patients. European Journal of Personality, 19, 229-247. https://doi.org/10.1002/per.546

Kulinna, P. H., \& Cothran, D. (2003). Physical Education Teachers' Self-Reported Use and Perceptions of Various Teaching Styles. Learning and Instruction, 13, 597-609. https://doi.org/10.1016/S0959-4752(02)00044-0

Kunter, M., Tsai, Y.-M., Klusmann, U., Brunner, M., Krauss, S., \& Baumert, J. (2008). Students' and Mathematics Teachers' Perceptions of Teacher Enthusiasm and Instruction. Learning and Instruction, 18, 468-482. https://doi.org/10.1016/j.learninstruc.2008.06.008

Kuppens, P., Van Mechelen, I., \& Rijmen, F. (2008). Towards Disentangling Sources of Individual Differences in Appraisal and Anger. Journal of Personality, 76, 69-100. https://doi.org/10.1111/j.1467-6494.2008.00511.x

Kyriacou, C. (2001). Teacher Stress: Directions for future research. Educational Review, 53, 27-35. https://doi.org/10.1080/00131910120033628

Labone, E. (2004). Teacher Efficacy: Maturing the Construct through Research in Alternative Paradigms. Teaching and Teacher Education, 20, 341-359. https://doi.org/10.1016/j.tate.2004.02.013

Lambert, L. G., McCarthy, C., O’Donnell, M., \& Wang, C. (2009). Measuring Elementary Teacher Stress and Coping in the Classroom: Validity Evidence for the Classroom Appraisal of Resources, and Demands. Psychology in the Schools, 46, 973-988. https://doi.org/10.1002/pits.20438

Largo-Wight, E., Peterson, M., Chen, W. (2005). Perceived Problem Solving, Stress, and Health among College Students. American Journal of Health Behavior, 29, 360-370. https://doi.org/10.5993/AJHB.29.4.8

Larson, L. M., \& Sailors, P. J. (1997). Perceived Effective Problem Solvers' Attributions Concerning Success and Failure of a Simulated Real-Life Problem. Behavior Modification, 21, 341-354. https://doi.org/10.1177/01454455970213005

Larson, L. M., Allen, S. J., Imao, R. A., \& Piersel, W. C. (1993). Self-Perceived Effective and Ineffective Problem Solvers' Differential Views of Their Partners' Problem-Solving Styles. Journal of Counseling and Development, 71, 528-532. https://doi.org/10.1002/j.1556-6676.1993.tb02236.x

Larson, L. M., Potenza, M. T., Wennstedt, L. W., \& Sailors, P. J. (1995). Personal Problem Solving in a Simulated Setting: Do Perceptions Accurately Reflect Behavior? Cognitive Therapy and Research, 19, 241-257.

Larson, L. M., Toulouse, A. L., Ngumba, W. E., Fitzpatrick, L. A., \& Heppner, P. P. (1994). The Development and Validation of Coping with Career Indecision. Journal of Career Assessment, 2, 91-110. https://doi.org/10.1177/106907279400200201

Lasky, S. (2000). The Cultural and Emotional Politics of Teacher-Parent Interactions. 
Teaching and Teacher Education, 16, 843-860.

https://doi.org/10.1016/S0742-051X(00)00030-5

Lazarus, R. S., \& Folkman, S. (1984). Stress, Appraisal, and Coping. New York: Springer.

Lazarus, R. S., DeLongis, A., Folkman, S., \& Gruen, R. (1985). Stress and Adaptational Outcomes: The Problem of Confounded Measures. American Psychologist, 40, 770-785. https://doi.org/10.1037/0003-066X.40.7.770

Lazarus, R., S. (1991). Emotions and Adaptation. New York: Oxford University Press.

Lazarus, R. S. (1993). From Psychological Stress to the Emotions: A History of Changing Outlooks. Annual Review of Psychology, 44, 1-21.

https://doi.org/10.1146/annurev.ps.44.020193.000245

Lazarus, R. S. (2006). Stress and Emotions: A New Synthesis. New York: Springer.

Lee, B., Cawthon, S., \& Dawson, K. (2013). Elementary and Secondary Teacher Self-Efficacy for Teaching and Pedagogical Conceptual Change in a Drama-Based Professional Development Program. Teaching and Teacher Education, 30, 84-98. https://doi.org/10.1016/j.tate.2012.10.010

Lewis, R. (1999). Teachers Coping with the Stress of Classroom Discipline. Social Psychology of Education, 3, 155-171. https://doi.org/10.1023/A:1009627827937

Lindsley, D. H., Brass, D. J., \& Thomas, J. B. (1995). Efficacy Performance Spirals: A Multilevel Perspective. Academy of Management Review, 20, 645-678.

Locke, E. A., \& Latham, G. P. (1990). A Theory of Goal Setting and Task Performance. Englewood Cliffs, NJ: Prentice-Hall.

Louis, K. S., \& Marks, H. M. (1998). Does Professional Community Affect the Classroom? Teachers' Work and Student Experience in Restructuring Schools. American Journal of Education, 106, 532-575. https://doi.org/10.1086/444197

Luszczynska, A., \& Schwarzer, R. (2005). Social Cognitive Theory. In M. Conner, \& P. Norman (Eds.), Predicting Health Behaviour (2nd Ed., pp. 127-169). Buckingham, UK: Open University Press.

MacNair, R. R., \& Elliott, T. R. (1992). Self-Perceived Problem-Solving Ability, Stress Appraisal, and Coping over Time. Journal of Research in Personality, 26, 150-164. https://doi.org/10.1016/0092-6566(92)90051-5

Mawhinney, H. B., Haas, J., \& Wood, C. (2005). Teachers' Perceptions of Collective Efficacy and School Conditions for Professional Learning. Nashville, TN: Annual Meeting of the University Council for Educational Administration.

Mayo, V. D., \& Tanaka-Matsumi, J. (1996). Think Aloud Statements and Solutions of Dysphoric Persons on a Social Problem-Solving Task. Cognitive Therapy and Research, 20, 97-113. https://doi.org/10.1007/BF02228029

McCormick, J. \& Barnett, K. (2011). Teachers' Attributions for Stress and Their Relationships with Burnout. International Journal of Educational Management, 25, 278-293. https://doi.org/10.1108/09513541111120114

Midgley, C., Feldlaufer, H., \& Eccles, J. (1988). The Transition to Junior High School: Beliefs of Pre- and Post-Transition Teachers. Journal of Youth and Adolescence, 17, 543-562. https://doi.org/10.1007/BF01537831

Midgley, C., Feldlaufer, H., \& Eccles, J. S. (1989). Change in Teacher Efficacy and Student Self- and Task-Related Beliefs in Mathematics during the Transition to Junior High School. Journal of Educational Psychology, 81, 247-258.

https://doi.org/10.1037/0022-0663.81.2.247

Midgley, C., Middleton, M. J., Gheen, M. H., \& Kummar, R. (2012). Stage-Environment 
Fit Revisited: A Goal Theory Approach to Examining School Transitions. In C. Midgley (Eds.), Goal Structures and Patterns of Adaptive Learning (pp. 109-142). New York: Routledge.

Mohamadi, F. S., \& Asadzadeh, H. (2012). Testing the Mediating Role of Teachers' Self-Efficacy Beliefs in the Relationship between Sources of Efficacy Information and Students' Achievement. Asia Pacific Educational Review, 13, 427-433. https://doi.org/10.1007/s12564-011-9203-8

Mojavezi, A., \& Tamiz, M. P. (2012). The Impact of Teacher Self-Efficacy on the Students' Motivation and Achievement. Theory and Practice in Language Studies, 2, 483-491. https://doi.org/10.4304/tpls.2.3.483-491

Morris, C. A. S., Denham, S. A., Bassett, H. H., \& Curby, T. W. (2013). Relations among Teachers' Emotion, Socialization, Beliefs and Practices, and Preschoolers' Emotional Competence. Early Education and Development, 24, 979-999. https://doi.org/10.1080/10409289.2013.825186

Motallebzadeha, K., Ashraf, H., \& Yazdi, M. T. (2014). On the Relationship between Iranian EFL Teachers' Burnout and Self-Efficacy. Procedia-Social and Behavioral Sciences, 98, 1255-1262. https://doi.org/10.1016/j.sbspro.2014.03.541

Muris, P. (2002). Relationships between Self-Efficacy and Symptoms of Anxiety Disorders and Depression in a Normal Adolescent Sample. Personality and Individual Differences, 32, 337-348. https://doi.org/10.1016/S0191-8869(01)00027-7

O’Leary, A. (1992). Self-Efficacy and Health: Behavioral and Stress-Physiological Mediation. Cognitive Therapy and Research, 16, 229-245. https://doi.org/10.1007/BF01173490

O’Neill, S., \& Stephenson, J. (2012). Exploring Australian Pre-Service Teachers' Sense of Efficacy, Its Sources, and Some Possible Influences. Teaching and Teacher Education, 28, 535-545. https://doi.org/10.1016/j.tate.2012.01.008

Pajares, F., \& Schunk, D. H. (2005). Self-Efficacy and Self-Concept Beliefs: Jointly Contributing to the Quality of Human Life. In H. W. Marsh, R. G. Craven, \& D. M. McInerney (Eds.), International Advances in Self Research (Vol. 2, pp. 95-122). Greenwich: Age Publishing.

Parrott, W. G. (2003). The Nature of Emotions. In A. Tesser, \& N. Schwarz (Eds.), Handbook of Social Psychology: Intraindividual Processes (pp. 375-390). Oxford: Blackwell.

Parto, M., \& Ali Besharat, M. (2011). Mindfulness, Psychological Well-Being and Psychological Distress in Adolescents: Assessing the Mediating Variables and Mechanisms of Autonomy and Self-Regulation. Procedia-Social and Behavioural Sciences, 30, 578-582. https://doi.org/10.1016/j.sbspro.2011.10.112

Pekrun, R., \& Bühner, M. (2014). Self-Report Measures of Academic Emotions. In P. A. Alexander, R. Pekrun, \& L. Linnenbrink-Garcia (Eds.), International Handbook of Emotions in Education (pp. 561-579). Oxon: Routledge.

Pekrun, R., \& Schutz, P. A. (2007). Where Do We Go from Here? Implications and Future Directions for Inquiry on Emotions in Education. In P. Schutz, \& R. Pekrun (Eds.), Emotion in Education (pp. 313-331). Academic Press: Amsterdam. https://doi.org/10.1016/B978-012372545-5/50019-8

Pekrun, R. (2005). Progress and Open Problems in Educational Emotion Research. Learning and Instruction, 15, 497-506. https://doi.org/10.1016/j.learninstruc.2005.07.014

Pekrun, R. (2006). The Control-Value Theory of Achievement Emotions: Assumptions, 
Corollaries, and Implications for Educational Research and Practice. Educational Psychology Review, 18, 315-341. https://doi.org/10.1007/s10648-006-9029-9

Pekrun, R., Frenzel, A., Goetz, T., \& Perry, R. P. (2007). The Control-Value Theory of Achievement Emotions: An Integrative Approach to Emotions in Education. In P. A. Schutz, \& R. Pekrun (Eds.), Emotion in Education (pp. 13-36). San Diego, CA: Academic Press.

Pekrun, R., Goetz, T., Daniels, L. M., Stupnisky, R. H., \& Perry, R. P. (2010). Boredom in Achievement Settings: Exploring Control-Value Antecedents and Performance Outcomes of a Neglected Emotion. Journal of Educational Psychology, 102, 531-549. https://doi.org/10.1037/a0019243

Pekrun, R., Goetz, T., Frenzel, A. C., Barchfeld, P., \& Perry, R. P. (2011). Measuring Emotions in Students' Learning and Performance: The Achievement Emotions Questionnaire (AEQ). Contemporary Educational Psychology, 36, 36-48. https://doi.org/10.1016/j.cedpsych.2010.10.002

Pekrun, R., Goetz, T., Titz, W., \& Perry, R. P. (2002). Academic Emotions in Students' Self-Regulated Learning and Achievement: A Program of Qualitative and Quantitative Research. Educational Psychologist, 37, 91-106. https://doi.org/10.1207/S15326985EP3702_4

Pekrun, R., Maier, M. A., \& Elliot, A. J. (2009). Achievement Goals and Achievement Emotions: Testing a Model of Their Relations with Academic Performance. Journal of Educational Psychology, 100, 115-135. https://doi.org/10.1037/a0013383

Pitkäniemi, H. (2017). A Teacher's Practical Theories, Self-Efficacy, and Emotions-What Connections Do They Have, and How Can They Be Developed? Nordisk Tidskrift för Allmän Didaktik, 3, 2-23.

Postareff, L., \& Lindblom-Ylänne, S. (2011). Emotions and Confidence within Teaching in Higher Education. Studies in Higher Education, 36, 799-813. https://doi.org/10.1080/03075079.2010.483279

Pretorius, T. B., \& Diedricks, M. (1994). Problem-Solving Appraisal, Social Support and Stress Depression Relationship. South African Journal of Psychology, 24, 86-90. https://doi.org/10.1177/008124639402400206

Radel, R., Sarrazin, P., Legrain, P., \& Wild, T. C. (2010). Social Contagion of Motivation between Teacher and Student: Analyzing Underlying Processes. Journal of Educational Psychology, 102, 577-587. https://doi.org/10.1037/a0019051

Reyna, C., \& Weiner, B. (2001). Justice and Utility in the Classroom: An Attributional Analysis of the Goals of Teachers' Punishment and Intervention Strategies. Journal of Educational Psychology, 93, 309-319. https://doi.org/10.1037/0022-0663.93.2.309

Rimm-Kaufman, S. E., \& Sawyer, B. E. (2004). Primary-Grade Teachers' Self-Efficacy Beliefs, Attitudes toward Teaching and Discipline and Teaching Practice Priorities in Relation to the "Responsive Classroom" Approach. The Elementary School Journal, 104, 321-341. https://doi.org/10.1086/499756

Rodrigo-Ruiz, D. (2016). Effect of Teachers' Emotions on Their Students: Some Evidence. Journal of Education \& Social Policy, 3, 73-79.

Roorda, D. L., Koomen, H. M. Y., Spilt, J. L., \& Oort, F. J. (2011). The Influence of Affective Teacher-Student Relationships on Students, School Engagement and Achievement: A Meta-Analytic Approach. Review of Educational Research, 81, 493-529. https://doi.org/10.3102/0034654311421793

Roseman I. J., \& Smith, C. A. (2001). Appraisal Theory: Overview, Assumptions, Varieties, Controversies. In K. R. Scherer, \& T. Johnson (Eds.), Appraisal Processes in Emo- 
tion: Theory, Methods, Research (pp. 3-18). Oxford: University Press.

Roseman, I. J. (2001). A Model of Appraisal in the Emotion System: Integrating Theory, Research and Applications. In: K. R. Scherer, A. Schorr, \& T. Johnstone (Eds.), Appraisal Processes in Emotion (pp. 68-91). Oxford, UK: Oxford University Press.

Ross, J. A. (1992). Teacher Efficacy and the Effect of Coaching on Student Achievement. Canadian Journal of Education, 17, 51-65. https://doi.org/10.2307/1495395

Ross, J. A. (1994). The Impact of an In-Service to Promote Cooperative Learning on the Stability of Teacher Efficacy. Teaching \& Teacher Education, 10, 381-394. https://doi.org/10.1016/0742-051X(94)90020-5

Ross, J. A. (1995). The Impact of an In-Service to Promote Cooperative Learning on the Stability of Teacher Efficacy. Teacher College Record, 97, 227-252.

Ross, J. A. (1998). The Antecedents and Consequences of Teacher Efficacy. In J. Brophy (Ed.), Advances in Research on Teaching (Vol. 7, pp. 49-73). Greenwich, CT: JAI Press.

Ross, J. A., Cousins, J. B., \& Gadalla, T. (1996). Within-Teacher Predictors of Teacher Efficacy. Teaching and Teacher Education, 12, 385-400. https://doi.org/10.1016/0742-051X(95)00046-M

Ross, J. A., Hogaboam-Gray, A., \& Gray, P. (2003). The Contribution of Prior Student Achievement and Collaborative School Processes to Collective Teacher Efficacy in Elementary Schools. Chicago: Annual Meeting of the American Educational Research Association.

Ross. J. A., \& Gray, P. (2006). Transformational Leadership and Teacher Commitment to Organizational Values: The Mediating Effects of Collective Teacher Efficacy. School Effectiveness and School Improvement, 17, 179-199. https://doi.org/10.1080/09243450600565795

Rotter, J. B. (1966). Generalized Expectancies for Internal versus External Control of Reinforcement. Psychological Monographs, 80, 1-28. https://doi.org/10.1037/h0092976

Sabourin, S., Laporte, L., \& Wright, D. (1990). Problem-Solving Selfappraisal and Coping Efforts in Distressed and Non-Distressed Couples. Journal of Marital and Family Therapy, 16, 89-97. https://doi.org/10.1111/j.1752-0606.1990.tb00048.x

Sahin, N., Sahin, N. H., \& Heppner, P. P. (1993). Psychometric Properties of the Problem Solving Inventory (PSI) in a Group of Turkish University Students. Cognitive Therapy and Research, 17, 379-396. https://doi.org/10.1007/BF01177661

Salanova, M., Cifre, E., Grau, R. M., Llorens, S., \& Martínez, I. M. (2005). Antecedentes de la autoeficacia en profesores y estudiantes universitarios: Un modelo causal [Antecedents of Self-Efficacy in College Teachers and Students: A Causal Model]. Revista de Psicología del Trabajo y de las Organizaciones, 21, 159-176.

Sander, D., Grandjean, D., \& Scherer, K. R. (2005). A Systems Approach to Appraisal Mechanisms in Emotion. Neural Networks, 18, 317-352. https://doi.org/10.1016/j.neunet.2005.03.001

Saric, M. (2015). Teachers' Emotions: A Research Review from a Psychological Perspective. Journal of Contemporary Educational Studies, 5, 10-25.

Sariçam, H., \& Sakız, H. (2014). Burnout and Teacher Self-Efficacy among Teachers Working in Special Education Institutions in Turkey. Educational Studies, 40, 423-437. https://doi.org/10.1080/03055698.2014.930340

Saunders, R. (2013). The Role of Teacher Emotions in Change: Experiences, Patterns and Implications for Professional Development. Journal of Educational Change, 14, 303-333. https://doi.org/10.1007/s10833-012-9195-0

Scherer, K. R. (2001). Appraisal Considered as a Process of Multilevel Sequential Check- 
ing. In K. R. Scherer, A. Schorr, \& T. Johnstone (Eds.), Appraisal Processes in Emotion: Theory, Methods, Research (pp. 92-120). Oxford: Oxford University Press.

Schmidt, S., Tinti, C., Levine, L. J., \& Testa, S. (2010). Appraisals, Emotions and Emotion Regulation: An Integrative Approach. Motivation and Emotion, 34, 63-72. https://doi.org/10.1007/s11031-010-9155-Z

Schunk, D. H., \& Meece, J. L. (2006). Self-Efficacy Development in Adolescence. In F. Pajares, \& T. Urdan (Eds.), Self-Efficacy Beliefs of Adolescents (pp. 71-96). Greenwich, CT: Information Age Publishing.

Schutz, P. A., \& DeCuir, J. T. (2002). Inquiry on Emotions in Education. Educational Psychologist, 37, 125-134. https://doi.org/10.1207/S15326985EP3702_7

Schutz, P. A., \& Lenehart, S. J. (2002). Emotions in Education. Educational Psychologist, 37, 67-78. https://doi.org/10.1207/S15326985EP3702_1

Schutz, P. A., \& Zembylas, M. (2009). Advances in Teacher Emotion Research: The Impact on Teachers' Lives. NY: Springer. https://doi.org/10.1007/978-1-4419-0564-2

Schutz, P. A., Hong, J. Y., Cross, D. I., \& Osbon, J. N. (2006). Reflections on Investigating Emotions among Educational Contexts. Educational Psychology Review, 18, 343-360. https://doi.org/10.1007/s10648-006-9030-3

Schutz, P., \& Davis, H. A. (2000). Emotions and Self-Regulation during Test Taking. Educational Psychologist, 35, 243-256. https://doi.org/10.1207/S15326985EP3504_03

Schwarzer, R., \& Hallum, S. (2008). Perceived Teacher Self-Efficacy as a Predictor of Job Stress and Burnout: Mediation Analyses. Applied Psychology: An International Review, 57, 152-171. https://doi.org/10.1111/j.1464-0597.2008.00359.x

Shapiro, S. (2010). Revisiting the Teachers' Lounge: Reflections on Emotional Experience and Teacher Identity. Teaching and Teacher Education, 26, 616-621.

https://doi.org/10.1016/j.tate.2009.09.009

Skaalvik, E. M., \& Skaalvik, S. (2014). Teacher Self-Efficacy and Perceived Autonomy: Relations with Teacher Engagement, Job Satisfaction, and Emotional Exhaustion. Psychological Reports, 114, 68-77. https://doi.org/10.2466/14.02.PR0.114k14w0

Skaalvik, E. M., \& Bong, M. (2003). Self-Concept and Self-Efficacy Revisited: A Few Notable Differences and Important Similarities. In H. W. Marsh, R. G. Craven, \& D. M. McInerney (Eds.), International Advances in Self Research (Vol. 1, pp. 67-89). Greenwich: Information Age Publishing Inc.

Skaalvik, E. M., \& Skaalvik, S. (2007). Dimensions of Teacher Self-Efficacy and Relations with Strain Factors Perceived Collective Teacher Efficacy and Teacher Burnout. Journal of Educational Psychology, 99, 611-625. https://doi.org/10.1037/0022-0663.99.3.611

Skaalvik, E. M., \& Skaalvik, S. (2016). Teacher Stress and Teacher Self-Efficacy as Predictors of Engagement, Emotional Exhaustion, and Motivation to Leave the Teaching Profession. Creative Education, 7, 1785-1799. https://doi.org/10.4236/ce.2016.713182

Skaalvik, E., \& Skaalvik, S. (2010). Teacher Self-Efficacy and Teacher Burnout: A Study of Relations. Teaching and Teacher Education, 26, 1059-1069. https://doi.org/10.1016/j.tate.2009.11.001

Smith, C. A., \& Lazarus, R. S. (1993). Appraisal Components, Core Relational Themes, and the Emotions. Cognition and Emotion, 7, 233-269. https://doi.org/10.1080/02699939308409189

Somech, A., \& Drach-Zahavy, A. (2000). Understanding Extra-Role Behavior in Schools: The Relationships between Job Satisfaction, Sense of Efficacy, and Teachers' Extra-Role Behavior. Teacher and Teacher Education, 16, 649-659.

https://doi.org/10.1016/S0742-051X(00)00012-3 
Stephanou, G. (2011). Students' Classroom Emotions: Socio-Cognitive Antecedents and School Performance. Electronic Journal of Research in Educational Psychology, 9, 5-48.

Stephanou, G., \& Mastora, M. (2013). Teachers' Attributions and Emotions for Their Teaching over a Kindergarten Year. International Journal of Advances in Psychology, 2, 137-156. https://doi.org/10.14355/ijap.2013.0203.01

Stephanou, G., \& Tsapakidou, A. (2007). Teachers' Teaching Styles and Self-Efficacy in Physical Education. International Journal of Learning, 14, 1-12. https://doi.org/10.18848/1447-9494/CGP/v14i08/45452

Stephanou, G., Gkavras, G., \& Doulkeridou, M. (2013). The Role of Teachers' Self- and Collective-Efficacy Beliefs on Their Job Satisfaction and Experienced Emotions in School. Psychology, 4, 268-278. https://doi.org/10.4236/psych.2013.43A040

Stephanou, G., Kariotoglou, P., \& Ntinas, K. (2011). University Students' Emotions in Lectures: The Effect of Competence Beliefs, Value Beliefs and Perceived Task-Difficulty, and the Impact on Academic Performance. International Journal of Learning, 18, 45-72.

Stetz, T. A., Stetz, M. C., \& Bliese, P. D. (2006). The Importance of Self-Efficacy in the Moderating Effects of Social Support on Stressor-Strain Relationships. Work \& Stress, 20, 49-59. https://doi.org/10.1080/02678370600624039

Summerfeldt, L. J., \& Endler, N. S. (1996). Coping with Emotion and Psychopathology. In M. Zeidner, \& N. S. Endler (Eds.), Handbook of Coping: Theory, Research, and Applications (pp. 602-639). New York: Wiley.

Summers, J. E., \& Davis, H. A. (2006). Introduction: The Interpersonal Contexts of Teaching, Motivation, and Learning. The Elementary School Journal: Special Issue on the Interpersonal Contexts of Motivation and Learning, 106, 189-192. https://doi.org/10.1086/501482

Sutton, R. E. (2000). The Emotional Experiences of Teachers. New Orleans, LA: Annual Meeting of the American Educational Research Association.

Sutton, R. E. (2007). Teachers' Anger, Frustration, and Self-Regulation. In P. A. Schutz, \& R. Pekrun (Eds.), Emotion in Education (pp. 259-274). Amsterdam: Elsevier Academic Press.

Sutton, R. E., \& Harper, E. (2009). Teachers' Emotion Regulation. In L. J. Saha \& A. G. Dworkin (Eds.), International Handbook of Research on Teachers and Teaching (pp. 389-401). New York: Springer.

Sutton, R. E., \& Mudrey-Camino, R. (2003). The Relationship among Teachers' Emotional Intensity, Emotional Regulation and Self-Efficacy. New Orleans, LA: Annual Meeting of the American Educational Research Association.

Sutton, R. E., \& Wheatley, K. E. (2003). Teachers' Emotions and Teaching: A Review of the Literature and Directions for Future Research. Educational Psychology Review, 15, 327-358. https://doi.org/10.1023/A:1026131715856

Sutton, R. E., Mudrey-Camino, R., \& Knight, C. C. (2009). Teachers' Emotion Regulation and Classroom Management. Theory into Practice, 48, 130-137. https://doi.org/10.1080/00405840902776418

Sutton, R. E. (2005). Teachers' Emotions and Classroom Effectiveness: Implications from Recent Research. Clearing House, 78, 229-234.

Takahashi, S. (2011). Co-Constructing Efficacy: A "Communities of Practice" Perspective on Teachers' Efficacy Beliefs. Teaching and Teacher Education, 27, 732-741.

https://doi.org/10.1016/j.tate.2010.12.002

Takaki, J., Nishi, T., Shimogama, H., Inada, T., Matsuyama, N., Kumano, H., \& Kuboki, T. (2003). Interaction among a Stressor, Depression, and Anxiety in Maintenance He- 
modialysis Patients. Behavioral Medicine, 29, 107-112.

https://doi.org/10.1080/08964280309596063

Taxer, J. L., \& Frenzel, A. C. (2015). Facets of Teachers' Emotional Lives: A Quantitative Investigation of Teachers' Genuine, Faked, and Hidden Emotions. Teaching and Teacher Education, 42, 78-88. https://doi.org/10.1016/j.tate.2015.03.003

Terry, D. (1994). Determinants of Coping: The Role of Stable and Situational Factors. Journal of Personality and Social Psychology, 66, 895-910. https://doi.org/10.1037/0022-3514.66.5.895

Tong, E. M. W., \& Jia, L. (2017). Positive Emotion, Appraisal, and the Role of Appraisal Overlap in Positive Emotion Co-Occurrence. Emotion, 17, 40-54.

https://doi.org/10.1037/emo0000203

Trigwell, K. (2012). Relations between Teachers' Emotions in Teaching and Their Approaches to Teaching in Higher Education. Instructional Science, 40, 607-621. https://doi.org/10.1007/s11251-011-9192-3

Tschannen-Moran, M., \& Johnson, D. (2011). Exploring Literacy Teachers' Self-Efficacy Beliefs: Potential Sources at Play. Teaching and Teacher Education, 27, 751-761. https://doi.org/10.1016/j.tate.2010.12.005

Tschannen-Moran, M., \& Barr, M. (2004). Fostering Student Learning: The Relationship of Collective Teacher Efficacy and Student Achievement. Leadership and Policy in Schools, 3, 189-209. https://doi.org/10.1080/15700760490503706

Tschannen-Moran, M., \& Hoy, A. W. (2007). The Differential Antecedents of Self-Efficacy Beliefs of Novice and Experienced Teachers. Teaching and Teacher Education, 23, 944-956. https://doi.org/10.1016/j.tate.2006.05.003

Tschannen-Moran, M., \& Woolfolk Hoy, A. (2001). Teacher Efficacy: Capturing an Elusive Construct. Teaching and Teacher Education, 17, 783-805. https://doi.org/10.1016/S0742-051X(01)00036-1

Tschannen-Moran, M., Hoy, A. W., \& Hoy, W. K. (1998). Teacher Efficacy: Its Meaning and Measure. Review of Educational Research, 68, 202-248. https://doi.org/10.3102/00346543068002202

Tsouloupas, C. N., Carson, R. L., Matthews, R., Grawitch, M. J., \& Barber, L. K. (2010). Exploring the Association between Teachers' Perceived Student Misbehaviour and Emotional Exhaustion: The Importance of Teacher Efficacy Beliefs and Emotion Regulation. Educational Psychology, 30, 173-189. https://doi.org/10.1080/01443410903494460

Turner, J. C., Meyer, D. K., Midgley, C., \& Patrick, H. (2003). Teacher Discourse and Sixth Graders' Reported Affect and Achievement Behaviors in Two Mastery/High Performance Mathematics Classrooms. Elementary School Journal, 103, 537-582. https://doi.org/10.1086/499731

Turner, J. C., Midgey, C., Meyer, D. K., Gheen, M., Anderman, E. M., \& Kang, Y. (2002). The Classroom Environment and Students' Reports of Avoidance Strategies in Mathematics: A Multi-Method Study. Journal of Educational Psychology, 94, 88-106. https://doi.org/10.1037/0022-0663.94.1.88

Vaezi, S., \& Fallah, N. (2011). The Relationship between Self-Efficacy and Stress among Iranian E.F.L. Teachers. Journal of Language Teaching and Resource, 2, 1168-1174.

Vauras, M., Salonen, P., Lehtinen, E., \& Kinnunen, R. (2009). Motivation in School from Contextual and Longitudinal Perspective. In M. Wosnitza, S. A. Karabenick, A. Efklides, \& P. Nenniger, (Eds.), Contemporary Motivation Research: From Global to Local Perspectives (pp. 1-24). Cambridge, MA: Hogrefe.

Wang, L., Heppner, P. P., \& Berry, T. R. (1997). Role of Gender-Related Personality 
Traits, Problem-Solving Appraisal, and Perceived Social Support in Developing a Mediational Model of Psychological Adjustment. Journal of Counseling Psychology, 44, 245-255. https://doi.org/10.1037/0022-0167.44.2.245

Warren, J. M., \& Dowden, A. R. (2012). Elementary School Teachers' Beliefs and Emotions: Implications for School Counselors and Counselor Educators. Journal of School Counseling, 10, 1-32.

Weiner, B. (1992). Human Motivation: Metaphors, Theories and Research. London: Sage.

Weiner, B. (2001). Intrapersonal and Interpersonal Theories of Motivation from an Attributional Perspective. Educational Psychology Review, 12, 1-14.

https://doi.org/10.1023/A:1009017532121

Weiner, B. (2005). Motivation from an Attribution Perspective and the Social Psychology of Perceived Competence. In A. J. Elliot, \& C. S. Dweck (Eds.), Handbook of Competence and Motivation (pp. 73-84). New York: Guilford.

Weiten, W., Dunn, D. S., \& Hammer, E. Y. (2011). Psychology Applied to Modern Life: Adjustment in the $21^{\text {st }}$ century $\left(10^{\text {th }} \mathrm{Ed}\right)$. USA: Wadsworth, Cengage Learning.

Wentzel, K. R. (1996). Social Goals and Social Relationships as Motivators of School Adjustment. In J. Juvonen, \& K. R. Wentzel (Eds.), Social Motivation: Understanding Children's School Adjustment (pp. 226-247). Cambridge: University Press.

Wheatley, K. F. (2005). The Case for Reconceptualizing Teacher Efficacy Research. Teaching and Teacher Education, 21, 747-766.

Witty, T. E., Heppner, P. P., Bernard, C. B., \& Thoreson, R. W. (2001). Problem-Solving Appraisal and Psychological Adjustment of Chronic Low Back Pain Patients. Journal of Clinical Psychology in Medical Settings, 8, 149-160.

https://doi.org/10.1016/j.tate.2005.05.009

Wolters, C. A., \& Daugherty, S. G. (2007). Goal Structures and Teachers' Sense of Efficacy: Their Relation and Association to Teaching Experience and Academic Level. Journal of Educational Psychology, 99, 181-193.

|https://doi.org/10.1037/0022-0663.99.1.181

Wong, C. A., \& Dornbusch, S. M. (2000). Adolescent Engagement in School and Problems Behaviors: The Role of Perceived Teacher Caring. New Orleans, LA: Annual Meeting of the American Educational Research Association.

Wong, P. T. P., \& Wong, L. C. J., Eds. (2006). Handbook of Multicultural Perspectives on Stress and Coping. New York: Springer. https://doi.org/10.1007/b137168

Woolfolk Hoy, A., \& Davis, H. (2005). Teachers' Sense of Efficacy and Adolescent Achievement. In T. Urdan, \& F. Pajares (Eds.), Adolescence and Education: Vol. 5: Self-Efficacy Beliefs during Adolescence (pp. 117-137). Greenwich, CT: Information Age.

Woolfolk, A. E., \& Hoy, W. K. (1990). Prospective Teachers' Sense of Efficacy and Beliefs about Control. Journal of Educational Psychology, 82, 81-91. https://doi.org/10.1037/0022-0663.82.1.81

Woolfolk, A. E., Rosoff, B., \& Hoy, W. K. (1990). Teachers' Sense of Efficacy and Their Beliefs about Managing Students. Teaching and Teacher Education, 6, 137-148. https://doi.org/10.1016/0742-051X(90)90031-Y

Wright, D. M., \& Heppner, P. P. (1991). Coping among Nonclinical College-Age Children of Alcoholics. Journal of Counseling Psychology, 38, 565-572. https://doi.org/10.1037/0022-0167.38.4.465

Yoon, J. S. (2002). Teacher Characteristics as Predictors of Teacher-Student Relationships: Stress, Negative Affect, and Self-Efficacy. Social Behavior and Personality, 30, 
485-493. https://doi.org/10.2224/sbp.2002.30.5.485

Yu, X., Wang, P., Zhai, X., Dai, H., \& Yang, Q. (2014). The Effect of Work Stress on Job Burnout among Teachers: The Mediating Role of Self-Efficacy. Social Indicators Research, 122, 701-708. https://doi.org/10.1007/s11205-014-0716-5

Zeidner, M., \& Endler, N. S., Eds. (1996). Handbook of Coping: Theory, Research, Applications. New York: Wiley.

Zembylas, M. (2002). "Structures of Feeling" in Curriculum and Teaching: Theorizing the Emotional Rules. Educational Theory, 52, 187-208.

https://doi.org/10.1111/j.1741-5446.2002.00187.x

Zembylas, M. (2003). Caring for Teacher Emotion: Reflections on Teacher Self-Development. Studies in Philosophy \& Education, 22, 103-125.

https://doi.org/10.1023/A:1022293304065

Zembylas, M. (2004). The Emotional Characteristics of Teaching: An Ethnographic Study of One Teacher. Teaching and Teacher Education, 20, 185-201.

https://doi.org/10.1016/j.tate.2003.09.008

Zimmerman, B. J., \& Geary, T. J. (2006). Adolescents' Development of Personal Agency. In F. Pajares, \& T. Urdan (Eds.), Adolescence and Education: Self-Efficacy Beliefs of Adolescents (pp. 45-69). Greenwich, CT: Information Age. 